medRxiv preprint doi: https://doi.org/10.1101/2022.01.26.22269752; this version posted January 28,2022 . The copyright holder for this preprint (which was not certified by peer review) is the author/funder, who has granted medRxiv a license to display the preprint in All rights reserved. No reuse allowed without permission.

\title{
IRE1 $\alpha$-XBP1 Activation Elicited by Viral Singled Stranded RNA via TLR8 May Modulate Lung Cytokine Induction in SARS-CoV-2 Pneumonia
}

José J. Fernández ${ }^{1}$, Cristina Mancebo ${ }^{1,2}$, Sonsoles Garcinuño ${ }^{3}$, Gabriel March $^{3}$, Yolanda Alvarez $^{1,2}$, Sara Alonso ${ }^{1}$, Luis Inglada ${ }^{4}$, Jesús Blanco ${ }^{5,6}$, Antonio Orduña ${ }^{3}$, Olimpio Montero ${ }^{1}$, Tito A. Sandoval ${ }^{7,8,9}$, Juan R. Cubillos-Ruiz ${ }^{7,8,9}$, Elena Bustamante ${ }^{10}$, Nieves Fernández ${ }^{1,2, \pi}$, Mariano Sánchez Crespo ${ }^{19 *}$

${ }^{1}$ Unidad de Excelencia Instituto de Biología y Genética Molecular, CSIC-Universidad de Valladolid, Spain

${ }^{2}$ Departamento de Bioquímica, Biología Molecular y Fisiología, Universidad de Valladolid, Spain

${ }^{3}$ Servicio de Microbiología, Hospital Clínico Universitario de Valladolid, Universidad de Valladolid, Spain

${ }^{4}$ Servicio de Medicina Interna, Hospital Universitario Rio-Hortega, Valladolid, Spain

${ }^{5}$ Servicio de Medicina Intensiva, Hospital Universitario Rio-Hortega, Valladolid, Spain

${ }^{6}$ CIBER de Enfermedades Respiratorias, Instituto de Salud Carlos III, Madrid, Spain

${ }^{7}$ Weill Cornell Graduate School of Medical Sciences, Cornell University, New York, NY, 10065, USA

${ }^{8}$ Department of Obstetrics and Gynecology, Weill Cornell Medicine, New York, NY, 10065, USA

${ }^{9}$ Sandra and Edward Meyer Cancer Center, Weill Cornell Medicine, New York, NY, 10065, USA

${ }^{10}$ Servicio de Medicina Intensiva, Hospital Clínico Universitario de Valladolid, Spain

* Corresponding author

E-mail: sanchezcrespomariano@gmail.com (M.S.C.)

"These authors contributed equally to this work.

NOTE: This preprint reports new research that has not been certified by peer review and should not be used to guide clinical practice. 
medRxiv preprint doi: https://doi.org/10.1101/2022.01.26.22269752; this version posted January 28,2022 . The copyright holder for this preprint (which was not certified by peer review) is the author/funder, who has granted medRxiv a license to display the preprint in All rights reserved. No reuse allowed without permission.

51

52

53

54

55

56

57

58

59

60

61

62

63

64

65

66

67

68

69

70

71

72

73

74

75

76

77

78

79

80

81

82

83

84

85

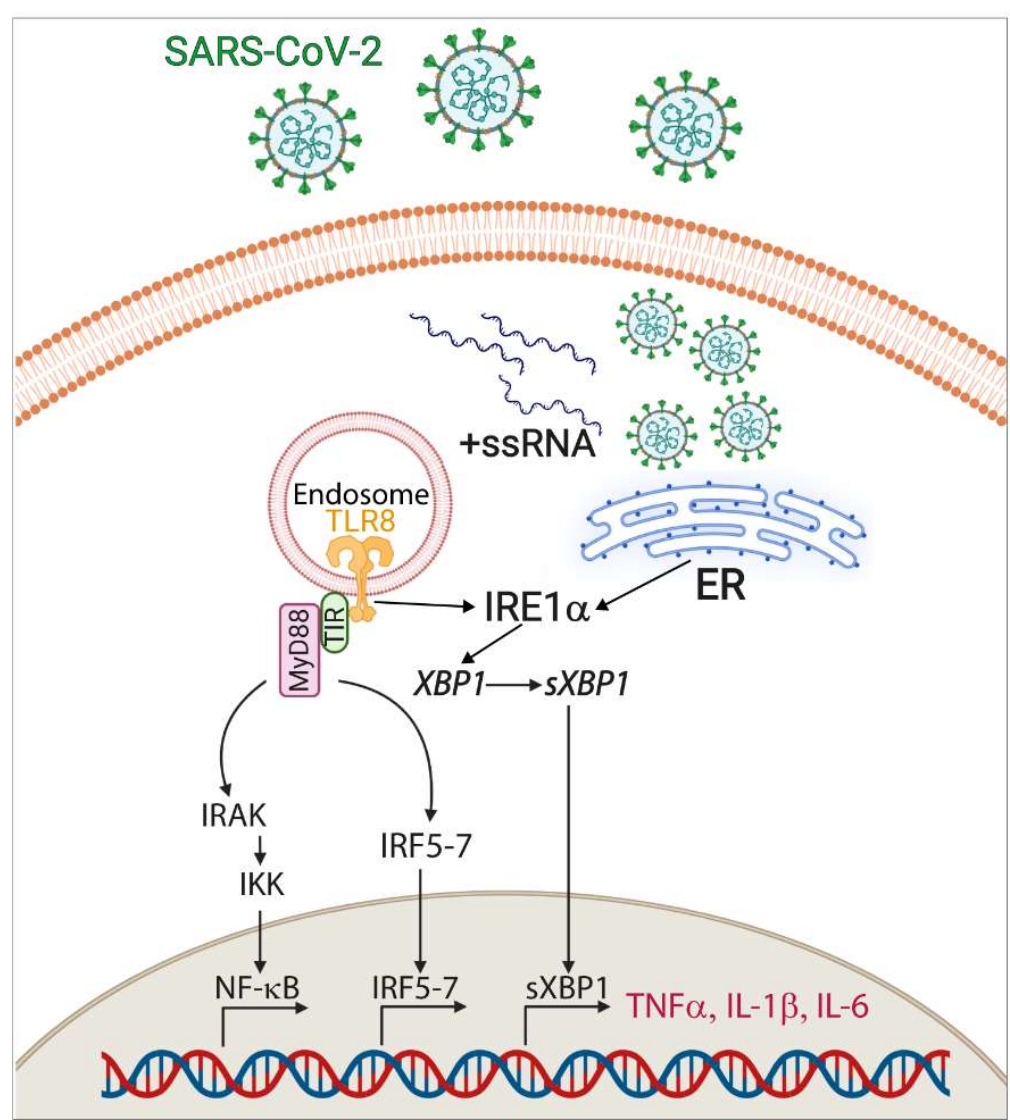

\section{Abstract}

Initial symptoms of COVID-19 infection depend on viral replication, while hyperinflammation is a hallmark of critical illness and may drive severe pneumonia and death. Among the mechanisms potentially involved in the hyperinflammatory state, we focused on the unfolded protein response, because the IRE1 $\alpha-\mathrm{XBP} 1$ branch can be activated as result of the endoplasmic reticulum stress produced by the overwhelming synthesis of viral components and synergizes with Toll-like receptor signaling to induce cytokine expression. Viral RNA may trigger the IRE1 $\alpha$-XBP1 branch via TLR7/8 activation and like TLR2 and TLR4 may underpin cytokine expression trough $X B P 1$ splicing $(s X B P 1)$. The expression of $I L 1 B, I L 6$, and $T N F$ 
medRxiv preprint doi: https://doi.org/10.1101/2022.01.26.22269752; this version posted January 28,2022 . The copyright holder for this preprint (which was not certified by peer review) is the author/funder, who has granted medRxiv a license to display the preprint in All rights reserved. No reuse allowed without permission.

86

87

88

mRNA in bronchoalveolar aspirates (BAAs) were higher in COVID-19 patients under mechanical ventilation and intubation who showed $s X B P 1$. The scrutiny of monocytic/macrophagic markers during active infection showed a reduction of those involved in antigen presentation and survival, as well as the IFN stimulated gene $M X 1$. These changes reverted after infection tests turned negative. In contrast, the expression of the mRNA of the serine protease TMPRSS2 involved in S protein priming showed a high expression during active infection. TLR8 mRNA showed an overwhelming expression as compared to TLR7 mRNA, which suggests the presence of monocyte-derived dendritic cells (MDDCs). In vitro experiments in MDDCs activated with ssRNA40, a positive-sense, single-stranded RNA (+ssRNA) like SARS-CoV-2 RNA, induced $s X B P 1$ and the expression of IL-1 $\beta$, IL-6, and TNF $\alpha$ at mRNA and protein levels. These responses were blunted by the IRE1 $\alpha$ ribonuclease inhibitor MKC8866. Given the analogies between the results observed in BAAs and the effects induced by + ssRNA in MDDCs, IRE1 $\alpha$ ribonuclease inhibition might be a druggable target in severe COVID-19 disease.

\section{Author summary}

COVID-19 pandemics put an unprecedented pressure on health systems. The need of new therapies urged research on the mechanisms triggered by the interaction of SARS-CoV-2 virus with host cells and the ensuing pathophysiology driving pneumonia and multiorgan failure. Hyperinflammation soon appeared as a mechanism involved in mortality that could even proceed after viral infection comes to an end. Hyperinflammation is supported by an inappropriate production of cytokines, and this explains the use of the term cytokine storm to refer to this phase of the disease.

Given that insight into the molecular mechanisms driving cytokine storm should focus on the interaction of viral components with immune cells, experiments addressing the effect of viral components on its cognate receptors were carried out. It was observed that viral RNA induces a cytokine pattern like the one observed in bronchoalveolar aspirates of COVID-19 patients with critical disease. Overall, the study revealed that both cell organelle overload and receptors involved in the recognition of viral RNA may team up to induce proinflammatory cytokines. This mechanism can be exploited to develop new treatments for COVID-19 disease. 
medRxiv preprint doi: https://doi.org/10.1101/2022.01.26.22269752; this version posted January 28,2022 . The copyright holder for this preprint (which was not certified by peer review) is the author/funder, who has granted medRxiv a license to display the preprint in All rights reserved. No perpetuity.

\section{Introduction}

Coronavirus disease 2019 (COVID-19) is a pandemic infection produced by severe acute influenza-like phase where fever and unproductive cough are predominant, but it can lead to severe respiratory insufficiency and multiorgan failure, which in many cases proceeds after infection resolution due to a hyperinflammatory response associated with the production of proinflammatory cytokines. The term cytokine storm was coined to refer to this condition [1], but the analysis of the immunopathological damage and the analogies with other viral diseases make it most appropriate the use of viral sepsis to depict the association of T-cell deficiencies with systemic hyperinflammation driven by virus-host cell interaction [2]. The use by viruses of the translational machinery of the host to produce their materials overloads many cellular functions, including protein folding and secretion in the endoplasmic reticulum (ER). Since only properly folded proteins should exit from the ER to maintain homeostasis, cells arrange a response directed to retain and degrade defective proteins. This involves an intracellular signaling pathway termed the unfolded protein response (UPR) [3-5]. The UPR includes a down regulation of global protein synthesis, the degradation of some proteins, and the transcriptional induction of specific genes associated with the activity of its three branches.

137 The most conserved one depends on the dual activity of inositol-requiring enzyme $1 \alpha(\operatorname{IRE} 1 \alpha)$, which shows protein kinase and endonuclease activities [6]. The endonuclease activity cleaves a 26- base fragment of the mRNA of the preformed transcript of $X B P 1$, which is followed by ligation of the resulting exons to yield $s X B P 1$. This drives the translation of the functionally active factor sXBP1 that trans-activates genes encoding proinflammatory proteins, e.g., the prostaglandin producing enzymes cyclooxygenase 2 and the microsomal isoform of 
medRxiv preprint doi: https://doi.org/10.1101/2022.01.26.22269752; this version posted January 28,2022 . The copyright holder for this preprint (which was not certified by peer review) is the author/funder, who has granted medRxiv a license to display the preprint in All rights reserved. No perpetuity.

prostaglandin synthase 2 [7], the ubiquitin-like modifier ISG15, and the cytokines IFN $\beta$, IL-6, IL-23, and TNF $\alpha[8-11]$.

Although the goal of the UPR is alleviating ER-stress, the IRE1 $\alpha$-XBP1 branch contributes to the pathogenesis of multiple ailments, including cancer, atherosclerosis, infections, and autoimmune diseases [12-15]. Recent research has disclosed that the IRE1 $\alpha-$ XBP1 branch enhances viral transcription and contributes to maintain dormant viral genomes in a host of infections $[16,17]$. The notion that UPR branches can mediate immune recognition of zoonotic viruses and drive acute lung injury through ER-stress mediated inflammation was disclosed by Hrincius et al. [18], who showed activation of the UPR by infection with poorly glycosylated pandemic strains of influenza A virus. The IRE1 $\alpha$ route was recruited, and its activation reduced when glycans were added to specific sites in the globular head of hemagglutinin. A study in cell lines infected with a SARS-CoV-2 isolate and lung biopsies of COVID-19 patients showed that SARS-CoV-2 hijacks the glycosylation biosynthetic machinery and drives ER-stress and UPR activation. This is due to the overwhelming asparagine $\mathrm{N}$-linked glycosylation required for the translation of viral glycoproteins, which forces aberrant glycosylation and ER-stress [19]. In keeping with notion, specific activation of sXBP1 has been reported in monocytes from COVID-19 patients [20].

The association of sXBP1 with TLR2 and TLR4 signaling [8] together with genuine UPR induced by protein synthesis overload point to SXBP1 involvement in the cytokine storm. [21]. The role of cytokine storm in COVID-19 disease was supported by the beneficial effect of tocilizumab, a humanized antihuman IL-6 receptor antibody [22]. This is noteworthy given the dependence of IL- 6 production on the IRE1 $\alpha-\mathrm{XBP} 1$ branch [8] and the presence in the proximal promoter of $I L 6$ of at least six sequences binding to sXBP1 [23]. Another potential interference of sXBP1 on COVID-19 illness stems from its blunting effect on dendritic cell homeostasis and the metabolic fitness of T-cells [24,25]. Likewise, the $\sigma 1$ receptor (S1R) 
medRxiv preprint doi: https://doi.org/10.1101/2022.01.26.22269752; this version posted January 28,2022 . The copyright holder for this preprint (which was not certified by peer review) is the author/funder, who has granted medRxiv a license to display the preprint in All rights reserved. No reuse allowed without permission.

reduces cytokine production in murine models of septic shock through IRE1 $\alpha$ endonuclease activity inhibition [14]. A new piece of evidence associating the UPR with COVID-19 illness was the induction of the UPR by ORF8 and S viral proteins, as well as the reduction of viral replication by pharmacological inhibition of the IRE1 $\alpha$ and ATF6 branches in epithelial cell lines [26]. In contrast, up-regulation of IRE1 $\alpha$ (RNase) activity by cannabidiol has been found to block SARS-CoV-2 replication in a cell line derived from lung epithelial cells and in lungs and nasal turbinates of infected mice [27].

Given that SARS-CoV-2 is a +ssRNA virus, the tandem TLR7/8 comes into prominence given its ability to bind viral RNA. Consistent with this notion, loss-of-function variants in X-chromosomal TLR7 have been reported in young patients with severe COVID19 disease, who showed impaired type I and II IFN responses [28]. The purpose of this study has been addressing how sXBP1 and TLR7/8 engagement may underpin viral sepsis in COVID-19 disease. To this end, samples of nasopharyngeal swabs and bronchoalveolar aspirates (BAAs) were studied to address the presence of $s X B P 1$, the cytokine-signature, and the expression of monocytic lineage cell markers and enzymes involved in energetic metabolism. After obtaining a profile of the transcriptional landscape, in vitro experiments were performed to address the transcriptional and energetic patterns of MDDCs stimulated with TLR7 and TLR8 agonists. Experiments showed that TLR8 activation of MDDCs induces a pattern of XBP1 splicing and cytokine expression, sensitive to inhibition of IRE1 $\alpha$ RNase activity, which mimics the pattern observed in BAAs. 
medRxiv preprint doi: https://doi.org/10.1101/2022.01.26.22269752; this version posted January 28,2022 . The copyright holder for this preprint (which was not certified by peer review) is the author/funder, who has granted medRxiv a license to display the preprint in All rights reserved. No reuse allowed without permission.

\section{Results}

\section{Studies in Nasopharyngeal Samples}

Initial assays were conducted in nasopharyngeal samples from patients receiving medical assistance for symptoms consistent with COVID-19 disease (Fig 1A). The extracted RNA was used for the diagnosis of SARS-CoV-2 infection and residual samples used for the assay of $s X B P 1$ by RT-PCR assays. This entails the separation of the PCR products by electrophoresis in agarose gel and densitometric analysis of GelRed stained bands. $s X B P 1$ is distinguished from unspliced $X B P 1(u X B P 1)$ by its faster migration. The position of the primers and the spliced region are shown in Fig 1B. These correspond to GenBank sequence NM_001079539.2, which differs from $u X B P 1$ sequence NM_005080.4 by the deletion of 26 nucleotides. Separate sequencing of the bands was used to confirm splicing (Fig 1C). A random selected array of RT-PCR negative and positive samples shows the presence of $u X B P 1$ and $s X B P 1$ (Fig 1D). The presence of three bands in some cases is explained by the formation of heteroduplexes [29]. $s X B P 1$ was detected in $17.91 \%$ of SARS-CoV-2 negative and $40.32 \%$ of SARS-CoV-2 positive patients (Fig 1E). Quantitation of $s X B P 1$ showed higher values in COVID-19 positive patients as compared to the negative ones (Fig 1F). The incidence of $s X B P 1$ was similar in male and females (Fig 1G) and increased with age (Fig 1H). Mortality was observed in four patients who showed a degree of splicing above $10 \%$ of total $X B P 1$ (Fig 1I). These findings show that $s X B P 1$ shows higher frequency and extent in nasopharyngeal exudates of patients with active SARS-CoV-2 infection, particularly in dying patients.

212 Further experiments were carried out using RNA extracted from BAAs of patients under 
medRxiv preprint doi: https://doi.org/10.1101/2022.01.26.22269752; this version posted January 28,2022 . The copyright holder for this preprint (which was not certified by peer review) is the author/funder, who has granted medRxiv a license to display the preprint in All rights reserved. No reuse allowed without permission.

endotracheal intubation were indicated because of acute hypoxemic respiratory failure despite high-flow nasal oxygen therapy or non-invasive ventilation. COVID-19 patients received a standard and proved useful treatment for the hyperinflammatory state consisting of $6 \mathrm{mg}$ dexamethasone daily or $50 \mathrm{mg}$ of IV hydrocortisone every 8 hours for up to 10 days, while this protocol was not routinely used in non-COVID-19 patients (Fig 2B). The extent of $s X B P 1$ was higher in SARS2-CoV-2 pneumonia patients than in those with respiratory failure due to other conditions, decreased after COVID-19 tests turned negative, and showed higher values than those observed in nasopharyngeal swabs (Fig 2C). The PERK-eIF2 $\alpha$-ATF4-CHOP branch of the UPR was explored assaying DDIT3/CHOP gene expression. DDIT3 expression also decreased after SARS-CoV-2 tests turned negative, while there was no significant difference of expression between non-COVID-19 and COVID-19 pneumonia patients (Fig 2D). As regards cytokine expression (Fig 2E-2N), IL1B and IL6 mRNA levels during viral proliferation were significantly lower than those detected in non-COVID-19 patients. A similar trend was observed in $T N F, I L 23 A$, and IL8 mRNA expression, although these values did not reach statistical significance. Cytokine mRNA did not show a trend to decrease after SARS-CoV-2 tests were negative. ILIO and IFNB mRNA were higher in SARS-CoV-2 infection than in nonCOVID pneumonia and continued elevated after COVID-19 tests turned negative. IFNG showed a trend to be increased in COVID-19 pneumonia. Overall, these results show that $s X B P 1$ in respiratory samples from COVID-19 patients does not associate with levels of cytokine expression higher than those observed in non-COVID-19 pneumonias. The high expression of IL10 mRNA suggests a parallel activation of an archetypal anti-inflammatory cytokine that might counter the inflammatory response. The increased expression of IFNBI mRNA is consistent with its involvement in viral sepsis. 
medRxiv preprint doi: https://doi.org/10.1101/2022.01.26.22269752; this version posted January 28,2022 . The copyright holder for this preprint (which was not certified by peer review) is the author/funder, who has granted medRxiv a license to display the preprint in All rights reserved. No reuse allowed without permission.

SARS-CoV-2 patients were stratified according to the presence or absence of both active infection and $s X B P 1$. Fig $3 \mathrm{~A}$ shows viral load in samples collected during infection and at the time when a negative COVID-19 test was first recorded. PTGS2 mRNA was higher in patients with $s X B P 1$ both during infection and after negativization of the RT-PCR test (Fig 3B). TNF and $I L 1 B$ mRNA expression was also higher in patients with $s X B P 1$, even after a negative RTPCR test (Fig 3C and 3D). IL6 mRNA was increased in patients with $s X B P 1$ and active infection (Fig 3E). IL8 mRNA was expressed at much lower levels than those encoding other cytokines, particularly after negativization of the infection in patients who did not show $s X B P 1$ (Fig 3F). IL10 mRNA was higher in SARS-CoV-2 positive patients who did not show $S X B P 1$ and remained elevated in patients showing $s X B P 1$ after resolution of the infection. These results show a high expression of the mRNA of $P T G S 2$ and several proinflammatory cytokines in patients with $S X B P 1$, which may persist after SARS-CoV-2 test becomes negative. The sustained expression of PTGS2 (COX2) mRNA suggests its involvement in either induction or repair of inflammatory damage [30]. Together, the results agree with the reported role of sXBP1 in the transcriptional activation of COX2, TNF $\alpha$, IL-1 $\beta$, and IL-6.

\section{Expression of Genes Involved in Glycolysis and Oxidative Phosphorylation (OXPHOS)}

Lymphocytes and myeloid cells respond to pathogen-associated molecular patterns (PAMPs) with a robust rewiring of their energetic metabolism driving increased glycolysis (Fig 4A). The impairment of $\mathrm{O}_{2}$ supply due to pneumonia further explains the resort to glycolysis and agrees with reports showing that SARS-CoV-2-induced metabolic reprogramming enhances the production of proinflammatory cytokines and IFNs by monocytes, and concomitantly inhibits T cell function $[31,32]$. Consistent with this notion, the expression of GLUT1 mRNA, a glucose transporter, and HIF $1 A$ mRNA, a transcription factor involved in the regulation of glycolytic enzymes, were increased during active infection. However, there was no difference as 
medRxiv preprint doi: https://doi.org/10.1101/2022.01.26.22269752; this version posted January 28,2022 . The copyright holder for this preprint (which was not certified by peer review) is the author/funder, who has granted medRxiv a license to display the preprint in All rights reserved. No reusetuity.

compared to non-COVID-19 pneumonia (Fig 4B and 4C). The mRNA encoding hexokinase II (Fig 4D), pyruvate dehydrogenase kinase IV (Fig 4F), malate dehydrogenase (MD) 2 (Fig 4G), and cis-aconitate dehydrogenase (IRG1 gene) (Fig 4K) increased during active infection as compared to both non-COVID-19 pneumonia and post-COVID infection. Notably, proteins involved in mitochondrial function also increased during COVID-19 pneumonia, i.e., succinate dehydrogenase subunit A (Fig 4I) and the 2-oxoglutarate-malate transporter SLC25A11, (Fig $4 \mathrm{~J})$. Together, these data show a resort to glycolysis during active SARS-CoV-2 infection that seems supported by the activity of HIF1and elements of the malate-aspartate shuttle such as MD2 and SLC25A11, which buttress the $\mathrm{NAD}^{+} / \mathrm{NADH}$ redox balance necessary for the progression of glycolysis at the glyceraldehyde 3-phosphate-dehydrogenase step.

\section{Characterization of Monocytic Markers in BAAs}

The first attempt to characterize the monocytic/macrophagic populations in BAAs focused on the expression of TLR7/8, given their involvement in the recognition of viral RNA. TLR8 mRNA was expressed to a far greater extent than TLR7 mRNA (Fig 5A), which agrees with the decay of TLR7 expression during the differentiation to MDDCs [33]. Further assay of markers showed a diminished expression of $H L A-D R B 1$ (Fig 5B), a gene involved in antigen presentation, CD300E (Fig 5C), a gene associated with survival signals, the chemokine receptor CCR2 (Fig 5D), and the IFN-stimulated gene (ISG) $M X 1$, (Fig 5G). Negativization of viral replication was associated with an increase of the expression of these genes, as well as the migration receptor $M M P 9$ (Fig 5E) and the MDDC differentiation marker BATF3 (Fig 5F). PTGS2/COX2 mRNA was similar in non-COVID and active COVID infection and decreased after RT-PCR test became negative (Fig 5I). The mRNA of the ISG OAS1 did not show significant changes during SARS-CoV-2 infection and increased after negativization of SARSCoV-2 test (Fig 5H). TMPRSS2 mRNA, a serine protease involved in the cleavage of viral 
medRxiv preprint doi: https://doi.org/10.1101/2022.01.26.22269752; this version posted January 28,2022 . The copyright holder for this preprint (which was not certified by peer review) is the author/funder, who has granted medRxiv a license to display the preprint in All rights reserved.

spike proteins [34] was significantly increased during SARS-CoV-2 active infection and (Fig 5J). These results disclose a differentiation profile during COVID-19 infection characterized by a low expression of markers associated with antigen presentation and survival signals, as well as $M X 1$. This is followed by an increase of the markers expressed in MDDCs in response to TLR ligands [33]. The high expression of TMPRSS2 mRNA underscores the role of TMPRSS2 in SARS-CoV-2 cell invasion and the low expression of $M X 1$ agrees with the reported association of single nucleotide polymorphisms within TMPRSS2 and near MX1 gene with severe COVID-19 disease [35]. A cogent explanation for the low $M X 1$ expression could be an evasive strategy of SARS-CoV-2 to avoid and/or shut down type I IFN responses [36].

Effects Induced by the Stimulation of Receptors Involved in the Recognition of Viral RNAs in MDDCs

Because SARS-CoV-2 is a +ssRNA virus, we posited that TLR7/8 might shape the innate immune response, given their endosomal location and accessibility to intracellular viral RNA. TLR7 and TLR8 expression in MDDCs mimicked the pattern observed in BAAs by showing a high expression of TLR8 and a low expression of TLR7 mRNA (Fig 6A). Activation of TLR7 by the selective ligand imiquimod showed a low extent of XBP1 splicing, even in real-time RT-PCR assays using a reverse primer overlaping the spliced region (Fig 6B). Consistent with the effect of palmitate as a potentiator of imiquimod effect via metabolic rewiring and $X B P 1$ splicing [11], the expression of proinflammatory cytokines increased in the presence of palmitate (Fig 6C-6F). In contrast, 2-deoxyglucose, which enhances $X B P 1$ splicing in the presence of some PAMPs [10] showed a limited effect. Given that IFN $\gamma$ teams up with TNF $\alpha$ to induce mortality in mice during SARS-CoV-2 infection [37] and it has been associated with the development of cytokine storm [38-41], the expression of ISGs was assayed. In contrast to IFNs, $M X 1$ and $O A S 1$ showed high levels of expression. The IRE1 $\alpha$ RNase inhibitor MKC8866 
medRxiv preprint doi: https://doi.org/10.1101/2022.01.26.22269752; this version posted January 28,2022 . The copyright holder for this preprint (which was not certified by peer review) is the author/funder, who has granted medRxiv a license to display the preprint in All rights reserved. No reuse allowed without permission.

[42] and the S1R agonist fluvoxamine, which has been reported to inhibit XBP1 splicing in bacterial sepsis [14], lacked any significant effect on those responses (Fig 6G-6J). Real-time assays of energetic metabolism with the Seahorse technology, showed a reduction of $\mathrm{O}_{2}$ consumption rate (OCR) and an increased extracellular acidification rate (ECAR) in response to imiquimod (Fig 6K), thus mimicking the glycolytic rewiring induced by bacterial PAMPs [43]. These effects were enhanced by metformin, a well-known inhibitor of the complex I of the electron transport chain (Fig 6L) that has been associated with a beneficial effect on the evolution of COVID-19 disease [44], most likely explained by its ability to reduce IL-1 $\beta$ and enhance IL-10 production [45]. Poly(cytidylic-inosinic) acid (poly(I:C)), a polyribonucleotide that mimics the effects of viral double-stranded RNA and activates TLR3, did not show any significant effect (Fig 6M).

In contrast to the limited effect of imiquimod, the TLR8 agonist ssRNA40, a 20-mer phosphorothioate protected single-stranded RNA oligonucleotide containing a GU-rich sequence, induced $s X B P 1$ in a similar way to the effect of the TLR2 agonist zymosan. The splicing was blocked by the IRE1 $\alpha$ RNase inhibitors MKC 8866 and $4 \mu 8 C$ (Fig 7A). MKC8866 also inhibited the expression of $I L 1 B, I L 6$, and $T N F$ mRNA (Figs 7B-7D) and protein (Fig 7E7F), thus resembling the cytokine signature detected in BAAs. ssRNA41, a ssRNA40 derivative wherein uracil nucleotides are replaced with adenosine and does not activate TLR8dependent signaling, did not induce cytokine expression, induced $s X B P 1$ to a low extent, and was less active than ssRNA40 to induce the aggregation of misfolded proteins, as deemed from the assay of aggresomes (S1A and S1B Fig). While pro-IL-1 $\beta$ expression increased in response to ssRNA40 (Fig 7G), IL-1 $\beta$ was not detected in MDDCs supernatants, thus suggesting that ssRNA40 does not activate the inflammasome and that an additional signal(s) is required for IL-1 $\beta$ secretion. The expression of IL- 6 and TNF $\alpha$ protein was inhibited by both MKC 8866 and fluvoxamine, which suggests that sXBP1 plays a significant role on the transcription of 
medRxiv preprint doi: https://doi.org/10.1101/2022.01.26.22269752; this version posted January 28,2022 . The copyright holder for this preprint (which was not certified by peer review) is the author/funder, who has granted medRxiv a license to display the preprint in All rights reserved. No reuse allowed without permission.

these cytokines. $I F N B 1, M X 1$, and $O A S 1$ mRNA were also induced by ssRNA40, while both MKC8866 and fluvoxamine only inhibited $M X 1$ and $O A S 1$ expression (Fig 7H-7K), thus suggesting a direct effect of sXBP1 on $M X 1$ and $O A S 1$ expression, rather than an indirect effect mediated by IFNs. Notably, ssRNA40 did not modify the energetic pattern of MDDCs (S1C Fig), which indicates that its ability to induce cytokine expression does not depend on blatant energetic changes. Unlike ssRNA40, zymosan, a ligand of TLR2 and C-type lectin receptors that mimics the external wall of fungi, induced a robust induction of glycolysis and OXPHOS as deemed from ECAR and OCR increases, respectively (S1D Fig).

To confirm the involvement of sXBP1 in the transcriptional activation of cytokines, its binding to the proximal promoter regions of $I L 1 B, I L 6$, and $T N F$ was assayed. Chromatin immunoprecipitation (ChIP) assays were conducted with primers spanning areas including consensus cis-regulatory elements associated with position weight matrices discovered in sXBP1 target promoters [23]. An increased binding of sXBP1 to the regions indicated in Fig 7L-N was observed after one hour of stimulation by ssRNA40. These results show that PAMPs acting on TLR8 induce a cytokine signature like that observed in BAAs and point to the central involvement of MDDCs in the innate immune response to SARS-CoV-2. The presence of $s X B P 1$ in nasopharyngeal swabs and BAAs, its induction by ssRNA40 in MDDCs, the effect of IRE1 $\alpha$ RNase inhibition on the cytokine induction produced by ssRNA40, and the demonstration of sXBP1 binding to the $I L 1 B, I L 6$, and TNF promoters suggest that TLR8induced $X B P 1$ splicing may contribute to the viral sepsis observed in severe cases of COVID19 disease. 
medRxiv preprint doi: https://doi.org/10.1101/2022.01.26.22269752; this version posted January 28,2022 . The copyright holder for this preprint (which was not certified by peer review) is the author/funder, who has granted medRxiv a license to display the preprint in All rights reserved. No perpetuity.

Discussion

Current pathogenetic views on COVID-19 pneumonia focus on immunopathological damage secretions allows the identification of the pathogens and can also give cues on pathogenesis [46-48]. This approach has been used in COVID-19 disease after the seminal studies by Zhou et al. [49] and Liao et al. [50], who used bronchoscopy and lavage to identify immune cell types in the respiratory tract. Our study focussed on patients under mechanical ventilatory support due to severe pneumonia, whose samples were obtained during routine care by attending staff [51-53]. This is in line with the use of tracheal aspirates to assess the transcriptional profiling of the lower respiratory tract in critically ill COVID-19 patients [54]. Initial assays showed higher degrees of $s X B P 1$ in COVID-19 disease than in patients with nonSARS-CoV-2 infection, although the mRNA levels of proinflammatory cytokines were higher in patients undergoing bacterial pneumonia. This was not fully unexpected, since cytokine storm is influenced by genetics and physiological conditions, in addition to cytokine levels [55,56]. Moreover, COVID-19 patients received steroids in a regular schedule, which contributes to reduce proinflammatory cytokines, and showed an overall mortality lower than that observed in non-COVID patients. Notably, inhibition of IRE1 $\alpha$ activity through activation of S1R by fluvoxamine protected mice from mortality during endotoxemia and fecal-induced peritonitis, as well as the production of IL-1 $\beta$, IL-6, and IL-12 p40 by human leukocytes [14]. Consistent with the experimental results, early fluvoxamine treatment in individuals with mild COVID-19 illness was associated with a reduction of signs of clinical deterioration as compared to the placebo group [57]. Similar results were reported in the TOGETHER trial, which involved larger cohorts for study and showed a significant reduction of morbidity by fluvoxamine, as deemed from a reduced resort to either retention in a COVID-19 emergency 
medRxiv preprint doi: https://doi.org/10.1101/2022.01.26.22269752; this version posted January 28,2022 . The copyright holder for this preprint (which was not certified by peer review) is the author/funder, who has granted medRxiv a license to display the preprint in All rights reserved. No perpetuity.

setting or transfer to tertiary hospital. Consistent with these findings, an independent data safety monitoring committee recommended stopping randomly assigning patients to the fluvoxamine arm in view of the superiority criterion for the primary endpoint [58]. Stratification of patients showing active infection and $s X B P 1$ disclosed the association of $s X B P 1$ with higher levels of cytokine expression and their decrease after infection negativization, thus suggesting that the effect of fluvoxamine may be due to inhibition of the IRE1 $\alpha$-XBP1 branch.

Secondary goals of the study were the characterization of enzymes involved in the bioenergetics and the identification of myeloid-lineage differentiation footprints. Bioenergetic screening suggested active glycolysis during SARS-CoV-2 infection supported by HIF1 and elements of the malate-aspartate shuttle. However, the predominance of glycolytic enzymes cannot be straightforwardly construed as a proof of aerobic glycolysis or Warburg effect given the compromise of $\mathrm{O}_{2}$ supply associated with SARS-CoV-2 pneumonia. The strong induction of IRGI/ACOD1 mRNA is consistent with its dependence on IFNs $[59,60]$. Notably, the ACOD1 product itaconate exerts antiviral activity and is considered a druggable target to counter the hyperinflammatory response [61].

Monocytic lineage cells are key players of the innate immune response due to their array of pattern recognition receptors and involvement in antigen presentation. BAAs showed a low expression of markers associated with antigen presentation, survival signals, and the ISG $M X 1$ during active infection. It is remarkable the low expression of $H L A-D R B 1$ mRNA, the gene encoding the most prevalent $\beta$-subunit of HLA-DR. This is in accordance with the decreased expression of HLA-DR in monocytes of COVID-19 patients, which drives hyperinflammation and defective antigen presentation mediated by IL-6 [62]. In contrast, the increased expression of TMPRSS2 mRNA agrees with the facilitating role of this transmembrane protease in viral infection by cleaving viral S glycoprotein. Tellingly, single 
medRxiv preprint doi: https://doi.org/10.1101/2022.01.26.22269752; this version posted January 28,2022 . The copyright holder for this preprint (which was not certified by peer review) is the author/funder, who has granted medRxiv a license to display the preprint in All rights reserved. No perpetuity.

nucleotide polymorphisms at 21q22.3 locus within TMPRSS2 and near MX1 genes have been associated with severe COVID-19 disease [35].

TLR7 and TLR8 are tandem duplicated genes on the X-chromosome, the function of which shows some commonalities and specificities. For instance, TLR8 is not functional in mice, and this explains the involvement of TLR7-induced cytokines in murine influenza [63]. TLR8 expression is a hallmark of human MDDCs, while TLR7 is present in monocytes, macrophages, and plasmacytoid dendritic cells [33]. A pioneering study addressing the pathophysiology of 2003 SARS-CoV-1 outbreak showed a unique ability of SARS-CoV-1 GUrich RNA sequences to induce proinflammatory cytokines through TLR7 in mice and TLR8 in human leukocytes [64]. This notion was extended in a recent report by comparing the effect of GU-rich RNAs on inflammasome activation and proinflammatory cytokine production. Notably, GU-rich RNA from the SARS-CoV-2 spike protein triggered the greatest inflammatory in human macrophages via TLR8 [65]. This agrees with our BAA and in vitro studies showing TLR8 as a central element in the recognition of +ssRNA virus and suggests a unique involvement of MDDCs and TLR8 in XBPlsplicing and hyperinflammation. Comparison of ssRNA40 and ssRNA41 effects show that TLR8-dependent signaling and sXBP1 are critical for cytokine expression, given the lack of effect of ssRNA41.

Activation of TLR7 by imiquimod induced a limited set of MDDC responses. However, it was remarkable the effect on energetic metabolism, characterized by a drop of the OCR and a parallel increase of ECAR, which mimicked the well-known effect of bacterial lipopolysaccharide. The effect on cytokines and $\triangle X B P 1$ was negligible and only reached significant values in the presence of palmitate. Unfortunately, our study does not contribute to answer open questions regarding the actual role of TLR7 in SARS-CoV-2 defense and immunopathology. TLR7 mutations driving loss-of-function in the antiviral response have been associated with severe forms of COVID-19 disease in young male [28]. Another study 
medRxiv preprint doi: https://doi.org/10.1101/2022.01.26.22269752; this version posted January 28,2022 . The copyright holder for this preprint (which was not certified by peer review) is the author/funder, who has granted medRxiv a license to display the preprint in All rights reserved. No reuse allowed without permission.

showed that while some TLR7 variants exhibit a robust loss-of-function on type I IFNs production, other variants only have a marginal effect, thus suggesting that TLR7 may shape the anti-viral response through additional mechanisms [66]. Moreover, autosomic inborn errors of TLR3- and IRF7-dependent type I IFN immunity were found in 23 out of 659 patients with severe COVID-19 pneumonia [67], thus stressing the role of type I IFNs in the protection against severe forms of COVID-19 pneumonia. Our data agree with Ito et al. [68] findings, who first disclosed that the TLR7/TLR8 agonist R848 was 100-fold as potent as imiquimod in human MDDCs. The absence of energetic rewiring induced by ssRNA40 could be explained by IFN $\beta$ effect, since IFN $\beta$ restrains aerobic glycolysis during mycobacteria infection. This drives mitochondrial stress and helps explain why type I IFN may cause damaging effects to the host [69]. Consistent with this interpretation is the lack of effect of poly(I:C), a selective activator of TLR3 that by using TRIF as the sole adaptor, activates IRF3 and ultimately induces type I IFNs. This is in shark contrast with the effect of zymosan, a ligand for TLR2 and the Ctype lectin receptor dectin-1 [70]. The binding of sXBP1 to IL1B, IL6, and TNF promoters induced by ssRNA40, together with the strong reduction of cytokine expression by an inhibitor of IRE1 $\alpha$ RNase, further indicates that the IRE1 $\alpha$-XBP1 branch underpins the production of cytokines via TLR8. These results assign to TLR8 capacities previously reported for TLR2 and TLR4, where sXBP1 is required for sustained production of proinflammatory cytokines. A corollary to these results is that inhibition of IRE1 $\alpha$ RNase activity could be a therapeutic approach for severe COVID-19 disease. 
medRxiv preprint doi: https://doi.org/10.1101/2022.01.26.22269752; this version posted January 28,2022 . The copyright holder for this preprint (which was not certified by peer review) is the author/funder, who has granted medRxiv a license to display the preprint in All rights reserved. No reuse allowed without permission.

Materials and Methods

Patients, Leukocyte Samples, and Ethic Statements

Nasopharyngeal samples were obtained from patients studied in different medical departments for symptoms consistent with SARS-CoV-2 infection at Hospital Clínico Universitario de Valladolid. In the case of patients with mechanical ventilation and intubation, samples were obtained by endotracheal aspirations to remove respiratory secretions as part of clinical care by the attending staff. This allows the obtention of material from the alveolar and respiratory bronchiole level. BAAs were directly transferred to the DNA/RNA extraction kit MagMAX ${ }^{\mathrm{TM}}$ Pathogen RNA/DNA (Applied Biosystems) for the automated extraction machine Kingfisher Flex (Thermo Fisher Scientific). Infection diagnosis was obtained using a TaqPath ${ }^{\mathrm{TM}}$ COVID19 RT-PCR kit assay from Applied Biosystems that targets N, ORF1a, and S genes. Resolution of infection was confirmed by the analysis of samples collected four days after a positive test. BAAs from non-COVID-19-patients were obtained from samples collected for microbiological diagnosis in patients suffering from severe bacterial pneumonia and requiring ventilatory support and intubation at ICU. Lung protective ventilation of both COVID-19 and nonCOVID-19 patients was performed according to the current guidelines on mechanical ventilation of acute respiratory distress syndrome in adult patients, which makes it unlike the induction of cytokine expression by mechanical ventilation [71]. The clinical part of the study was approved by the Ethics Committee of Area de Salud Valladolid Este (ref. PI-GR-20-2011 COVID). For in vitro experiments, MDDCs were obtained from human mononuclear cells collected from pooled buffy coats of healthy donors provided by Centro de Hemoterapia y

477 Hemodonación de Castilla y León Biobank. The study was approved by the Bioethical Committee of the Spanish Council of Research (CSIC) and the written informed consent of all healthy donors was obtained at Centro de Hemoterapia y Hemodonación de Castilla y León 
medRxiv preprint doi: https://doi.org/10.1101/2022.01.26.22269752; this version posted January 28,2022 . The copyright holder for this preprint (which was not certified by peer review) is the author/funder, who has granted medRxiv a license to display the preprint in All rights reserved. No reuse allowed without permission.

480

481

482

483

484

485

486

487

488

489

490

491

492

493

494

495

496

497

498

499

500

501

502

503

504

Biobank. The researchers received the samples in an anonymous way. The process is documented by the Biobank authority according to the specific Spanish regulations. The ethics committee approved this procedure before starting the study. The differentiation of monocytes was carried out in the presence of GM-CSF and IL-4 for 5 days. Culture was carried out in RPMI 1640 medium containing $11.1 \mathrm{mM}$ D-glucose and $4 \mathrm{mM} \mathrm{L-glutamine.} \mathrm{10 \%} \mathrm{FBS} \mathrm{was}$ maintained during the differentiation process and reduced to $2 \%$ at the start of experiments. Imiquimod (Sigma-Aldrich), ssRNA40/LyoVec ${ }^{\mathrm{TM}}$, and its negative control ssRNA41/LyoVec ${ }^{\mathrm{TM}}$ (InvivoGen) were used as TLR7 and TLR8 selective ligands in MDDCs. MKC8866 was from MedChemExpress.

\section{XBP1 Splicing Assay}

This was carried out by RT-PCRs using primers outside the spliced region. The PCR conditions were 5 min at $95^{\circ} \mathrm{C}$ (hot start), 45 cycles of denaturation at $95^{\circ} \mathrm{C}$ for $15 \mathrm{~s}$, annealing at $60^{\circ} \mathrm{C}$ for $20 \mathrm{~s}$ and elongation at $72^{\circ} \mathrm{C}$ for $1 \mathrm{~min}$. Final extension was carried out at $72^{\circ} \mathrm{C}$ for $5 \mathrm{~min}$. Gel electrophoresis was carried out in $3 \%$ agarose and $s X B P 1$ and $u X B P 1$ bands were visualized by GelRed ${ }^{\circledR}$ staining and quantified using GelDoc Go Image System (Bio-Rad).

\section{Real-Time RT-PCR and Protein Assays}

Total RNA obtained by automatic extraction was used for RT reactions. The resulting cDNA was amplified in a LightCyclerß 480 equipment using SYBR Green I mix containing Hot Start polymerase. Cycling conditions were adapted to each set of primers. ACTB was used as a housekeeping gene to assess the relative abundance of the different mRNA using the comparative cycle threshold method. The procedure was used to assay $X B P 1, D D I T 3, I L 1 B$, IL6, IL10, IL23A, TNF, SLC25A11, GLUT1, HK2, PFKB3, PDK4,IDH1, IDH2, SDHA, MDH2, HIF1A, TLR7, TLR8, HLA-DRB1, CD300E, CCR2, MMP9, BATF3, MX1, OAS1, 
medRxiv preprint doi: https://doi.org/10.1101/2022.01.26.22269752; this version posted January $28,2022$. The copyright holder for this preprint (which was not certified by peer review) is the author/funder, who has granted medRxiv a license to display the preprint in perpetuity.

All rights reserved. No reuse allowed without permission.

PTGS2, and TMPRSS2 mRNA. Primer sequences are shown in Table 1. IL-6 and TNF $\alpha$

proteins were assayed in supernatants of MDDCs stimulated with ssRNA40 using kits from

Technology.

Table 1. Sequences of primers used for qRT-PCR and ChIP assays

\begin{tabular}{|c|c|c|}
\hline GENE & Forward primer & Reverse primer \\
\hline$X B P 1$ & 5'- TGAGCTGGAACAGCAAGTGG -3' & 5'- ATACCGCCAGAATCCATGGGGA -3' \\
\hline$s X B P 1$ & 5'- TGAGCTGGAACAGCAAGTGC -3' & 5'- CTGCACCTGCTGCGGACTCA -3' \\
\hline DDIT3 & 5'- GCAGAGATGGCAGCTGAGTC -3' & 5'- AGCCAAGCCAGAGAAGCAGGGT -3' \\
\hline$I L 1 B$ & 5'- ATGATGGCTTATTACAGTGGCAA -3' & 5'- GTCGGAGATTCGTAGCTGGA -3' \\
\hline$T N F$ & 5'-GTTGTAGCAAACCCTCAAGC-3' & 5'TTGAAGAGGACCTGGGAGTA-3' \\
\hline IL6 & 5'- TTCGGTACATCCTCGACGGC -3' & 5'- TCTGCCAGTGCCTCTTTGCT -3' \\
\hline IL8 & 5'- ATTTCTGCAGCTCTGTGTGAA -3' & 5'- AACTTCTCCCGACTCTTAAGT -3' \\
\hline IL10 & 5'-GAGAACAGCTGCACC CAC TT-3' & 5'-GGCCTTGCTCTTGTT TTCAC-3' \\
\hline IL23A & 5`-GTTCCCCATATCCAGTGTGG -3' & 5'- TTAGGGACTCAGGGTTGCTG -3' \\
\hline IL12B & 5'- CATGGGCCTTCATGCTATTT -3' & 5'- TTTGCATTGTCAGGTTTCCA -3' \\
\hline IFNBI & 5'- TCTAGCACTGGCTGGAATGAG- 3' & 5'- GTTTCGGAGGTAACCTGTAAG-3' \\
\hline$I F N G$ & 5'-CCAACGCAAAGCAATACATGA-3' & 5'-CCTTTTTCGCTTCCCTGTTTTA-3' \\
\hline N Gene & 5'- CAATGCTGCAATCGTGCTAC -3' & 5'- GTTGCGACTACGTGATGAGG -3' \\
\hline $\mathrm{COX} 2$ & 5'- TTCAAATGAGATTGTGGGAA -3' & 5'- AGATCATCTCTGCCTGAGTA -3' \\
\hline GLUT1 & 5'- GAAGAGAGTCGGCAGATGAT- 3' & 5'- AATAGAAGACAGCGTTGATGC -3' \\
\hline HIF1A & 5'-AGTGTACCCTAACTAGCCGA-3' & 5'-GTGCAGTGCAATACCTTCC-3' \\
\hline$H K 2$ & 5'- TAGGGCTTGAGAGCACCTGT -3' & 5'- CCACACCCACTGTCACTTTG -3' \\
\hline PFKFB3 & 5'-CCGTTGGAACTGACGCAGA -3' & 5'-CACAGGATCTGGGCAACGAG-3' \\
\hline$P D K 4$ & 5'-CCCGCTGTCCATGAAGCAGC -3' & 5'-CCAATGTGGCTTGGGTTTCC-3' \\
\hline$M D H 2$ & 5'- TCGGCCCAGAACAATGCTAAA -3' & 5'- GCGGCTTTGGTCTCGATGT -3' \\
\hline$I D H 2$ & 5'- TGGCTCAGGTCCTCAAGTCT -3' & 5'- CTCAGCCTCAATCGTCTTCC -3' \\
\hline SDHA & 5'- CAGCATGTGTTACCAAGCT -3' & 5' -GGTGTCGTAGAAATGCCAC -3' \\
\hline SLC25A11 & 5'- ACACCGTCCTCACCTTCATC -3' & 5'- CAGGGGGTAGAACAGACCAA -3' \\
\hline IRG1 & 5'- GTTCCTGGGAACCACTACG -3' & 5'- GATGTCTGGCTGACCCCAA -3' \\
\hline$T L R 7$ & 5'-CTTGGCACCTCTCATGCTCT-3' & 5'-GTCTGTGCAGTCCACGATCA-3' \\
\hline TLR8 & 5' -GCTGACCTGCATTTTCCTGC-3' & 5'-CCGTTTGGGGAACTTCCTGT-3' \\
\hline HLA-DRB1 & 5' -TTCCTGTGGCAGCCTAAGAG-3' & 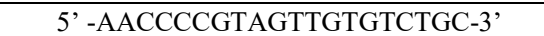 \\
\hline CD300E & 5' -AGAGAAGGTGGAGAGGAATGG-3' & 5' -AGGAAGATGGGAGGTGTGG-3' \\
\hline$C C R 2$ & 5'-CCCCAACGAGGCATAGA -3' & 5'- AAGAGTCTCTGTCACCTGCG -3' \\
\hline$M M P 9$ & 5' -CGTCTTCCCCTTCACTTTCC-3 & 5' -CCCCACTTCTTGTCGCTGT-3' \\
\hline BATF3 & 5' -AGGAAGGTCCGAAGGAGAGA-3' & 5' -GAGGCACTGGCACAAAGTTC-3' \\
\hline$M X 1$ & 5' -CTGGGATTTTGGGGCTTT-3' & 5' -GGGATGTGGCTGGAGATG-3' \\
\hline OAS1 & 5' - TCAGAAATACCCCAGCCAAA-3' & 5'-GAGCCACCCTTTACCACCTT-3' \\
\hline TMPRSS2 & 5'-CCTCTAACTGGTGTGATGGCGT-3’ & 5'-TGCCAGGACTTCCTCTGAGATG-3' \\
\hline \multirow[t]{2}{*}{$A C T B$} & 5'-CTGTCTGGCGGCACCACCAT-3' & 5'-GCAACTAAGTCATAGTCCGC-3' \\
\hline & ChIP Assays Primers & \\
\hline PROMOTER & Forward Primer & Reverse Primer \\
\hline IL1B Proximal & 5'-TAGTTTGCTACTCCTTGCCCT-3' & 5'-AGGAAAGGGGAAAAGAGTATTGGT-3' \\
\hline IL1B Medial & 5'-TGAATGAAGAAAAGTATGTGCATGT-3' & 5'-AAATACTGGATTTTCCCACGTTAG-3' \\
\hline IL6 Proximal & 5-AGCCTCAATGACGACCTAAGC-3 & 5'-GGGTGGGGCTGATTGGAAA-3' \\
\hline IL6 Medial & 5'-ACCTTCTTCATAATCCCAGGC-3' & 5'-AGGCTAGAATTTAGCGTTCCAGT-3' \\
\hline TNF Proximal & 5'-ATGCTTGTGTGTCCCCAACT-3' & 5'-CAGCGGAAAACTTCCTTGGTG-3' \\
\hline TNF Medial & 5'-GACCCAAACACAGGCCTCA-3' & 5'ACTAGAACTGGGAGGGGCTT-3' \\
\hline TNF Distal & 5'-GTCCAGGGCTATGGAAGTCG-3' & 5'-CCCAGTGTGTGGCCATATCTT-3' \\
\hline
\end{tabular}


medRxiv preprint doi: https://doi.org/10.1101/2022.01.26.22269752; this version posted January 28,2022 . The copyright holder for this preprint (which was not certified by peer review) is the author/funder, who has granted medRxiv a license to display the preprint in All rights reserved. No perpetuity.

514 Bioenergetic assays were carried out using an Agilent Seahorse XF HS Mini Analyzer. $10^{5}$ MDDCs were adhered with Cell-Tak® to Seahorse plates and treated with stimuli of TLR3, TLR7, and TLR8, as well as sonicated zymosan to activate the fungal pattern receptor dectin1 and TLR2, after a stabilization period. OCR and ECAR were analyzed according to the XF Cell Mito Stress Test kit protocol in XF media under the experimental conditions and in response to metformin, oligomycin, FCCP, and rotenone plus antimycin A.

\section{Aggresome Formation Assay}

The formation of aggresomes due to ER stress was assayed by flow cytometry fluorescence using the Proteostat ${ }^{\circledR}$ aggresome detection kit of ENZO according to the manufacturer's instructions. The proteasome inhibitor MG132 was used as a positive control. MDDCs were incubated under different conditions and then fixed, stained with Proteostat ${ }^{\circledR}$ dye and used for the assay of fluorescence in a Gallios flow cytometer at $488 \mathrm{~nm}$ in the FL3 channel using the Kaluza software version 1.1 for quantitative analysis (Beckman Coulter Life Sciences).

\section{Chromatin Immunoprecipitation (ChIP) Assay}

Chromatin immunoprecipitation assays were conducted using a rabbit mAb (Cell Signaling Technology) against sXBP1 as previously reported [10]. Briefly, MDDCs were stimulated, washed with PBS, and fixed with $1 \%$ formaldehyde. Cross-linking was terminated by $0.125 \mathrm{M}$ glycine. Crude nuclear extracts were collected by microcentrifugation. Chromatin sonication was carried out using a Bioruptor device (Diagenode). The chromatin solution was precleared by adding Protein A/G PLUS-Agarose for $30 \mathrm{~min}$ at $4^{\circ} \mathrm{C}$ under continuous rotation. After elimination of the beads, mAb was added for overnight incubation at $4^{\circ} \mathrm{C}$, and then Protein A/G PLUS-Agarose was added and incubated for an additional period of $2 \mathrm{~h}$ at $4^{\circ} \mathrm{C}$. Beads were harvested by centrifugation at 4,000 $\mathrm{x} g$ and sequentially washed with lysis buffer high 
medRxiv preprint doi: https://doi.org/10.1101/2022.01.26.22269752; this version posted January 28,2022 . The copyright holder for this preprint (which was not certified by peer review) is the author/funder, who has granted medRxiv a license to display the preprint in All rights reserved. No reuse allowed without permission.

539

540

541

542

543

544

545

546

547

548

549

550

551

552

553

554

555

556

557

558

559

560

561

562

salt, wash buffer, and elution buffer. Cross-links were reversed by heating at $67^{\circ} \mathrm{C}$ in a water bath, and the DNA bound to the beads isolated by extraction with phenol/chloroform/isoamylalcohol. Irrelevant $\mathrm{Ab}$ was used as control of binding specificity. The sequences of the primers are shown in Table 1. Results are expressed as percentage of input.

\section{Quantification and Statistical Analysis}

Data are represented as the mean \pm SEM and were analyzed with the Prism 9.0 statistical program. Repeated measures one-way and two-way ANOVA analyses were performed. When data did not follow normal distribution nor had equal variances, log-transformation was applied before analysis. Comparison between experimental groups was carried out using unpaired or paired two-tailed Student's $t$-test and Wilkoxon signed-rank test, and Welch`s test. Statistical details are shown in the Fig legends. Differences were considered significant for $\mathrm{p}<0.05$.

\section{ACKNOWLEDGMENTS}

José Javier Fernández is the recipient of a grant from Junta de Castilla y León. Cristina Mancebo is the recipient of a pre-doctoral grant from the Valladolid Section of Asociación Española contra el Cáncer (AECC). Biobanco del Centro de Hemoterapia y Hemodonación de Castilla y León is thanked for providing buffy coats. Staff from the Intensive Care Unit of Hospital Clínico Universitario de Valladolid is thanked for the effort devoted to patient followup care and sample collection. BioRender.com software was used in some figures.

\section{AUTHOR CONTRIBUTIONS}


medRxiv preprint doi: https://doi.org/10.1101/2022.01.26.22269752; this version posted January 28,2022 . The copyright holder for this preprint (which was not certified by peer review) is the author/funder, who has granted medRxiv a license to display the preprint in All rights reserved. No reuse allowed without permission.

564 Conceptualization: Antonio Orduña, Juan Cubillos-Ruiz, Elena Bustamante, Nieves 565 Fernández, Mariano Sánchez Crespo.

566 Data curation: José J. Fernández, Sonsoles Garcinuño, Gabriel March, Luis Inglada, Antonio 567 Orduña, Juan Cubillos-Ruiz, Elena Bustamante, Mariano Sánchez Crespo.

568 Formal analysis: José J. Fernández, Yolanda Alvarez, Luis Inglada, Jesús Blanco, Antonio 569 Orduña, Elena Bustamante, Nieves Fernández, Mariano Sánchez Crespo.

570 Funding acquisition: Nieves Fernández, Mariano Sánchez Crespo.

571 Investigation: José J. Fernández, Cristina Mancebo, Sonsoles Garcinuño, Gabriel March, 572 Yolanda Alvarez, Sara Alonso, Luis Inglada, Jesús Blanco, Antonio Orduña, Olimpio Montero, 573 Tito A. Sandoval, Juan Cubillos-Ruiz, Elena Bustamante, Nieves Fernández, Mariano Sánchez 574 Crespo.

Methodology: José J. Fernández, Cristina Mancebo, Sonsoles Garcinuño, Gabriel March, Blanco, Tito A. Sandoval, Antonio Orduña, Elena Bustamante.

Project administration: Nieves Fernández.

579 Resources: Nieves Fernández.

Supervision: Nieves Fernández, Mariano Sánchez Crespo. Fernández.

Visualization: José J. Fernández, Nieves Fernández, Mariano Sánchez Crespo.

Writing - original draft: Luis Inglada, Jesús Blanco, Tito A. Sandoval, Juan Cubillos-Ruiz, Nieves Fernández, Mariano Sánchez Crespo. 
medRxiv preprint doi: https://doi.org/10.1101/2022.01.26.22269752; this version posted January $28,2022$. The copyright holder for this preprint (which was not certified by peer review) is the author/funder, who has granted medRxiv a license to display the preprint in All rights reserved. No reuse allowed without permission.

FUNDING

590

591 This study was funded by Fondo COVID-19 del Instituto de Salud Carlos III/Junta de Castilla

592 y León (N.F.). European Commission-NextGenerationEU, through CSIC's Global Health

593 Platform (PTI Salud Global) (project SGL2103016) (M.S.C.). Plan Nacional de Salud y

594 Farmacia Grant SAF2017-83079-R and Grant PID2020-113751RB-I00 funded by

595 MCIN/AEI/ 10.13039/501100011033 (M.S.C.). Junta de Castilla y León/Fondo Social

596 Europeo Grants CSI035P17 (M.S.C.) and VA175P20 (N.F.). Proyecto SEAHORSE

597 INFRARED: IR2020-1-UVA05 (JCyL). The funders had no role in study design, data

598 collection and analysis, decision to publish, or preparation of the manuscript.

599

600 
medRxiv preprint doi: https://doi.org/10.1101/2022.01.26.22269752; this version posted January 28,2022 . The copyright holder for this preprint (which was not certified by peer review) is the author/funder, who has granted medRxiv a license to display the preprint in All rights reserved. perpetuity.

601

602

603

604

605

606

607

608

609

610

611

612

613

614

615

616

617

618

619

620

621

622

623

624

625

626

627

628

629

630

631

\section{REFERENCES}

1. Fajgenbaum DC, June CH. Cytokine storm. N Engl J Med. 2020;383: 2255-2273.

2. Riva G, Nasillo V, Tagliafico E, Trenti T, Comoli P, Luppi M. COVID-19: more than a cytokine storm. Crit. Care. 2020;24: 549.

3. Hetz C, Zhang K, Kaufman RJ. Mechanisms, regulation and functions of the unfolded protein response. Nat Rev Mol Cell Biol. 2012;13: 89-102.

4. Bettigole SE, Glimcher LH. Endoplasmic reticulum stress in immunity. Annu Rev Immunol. 2015;33: 107-138.

5. Chen X, Cubillos-Ruiz, JR. Endoplasmic reticulum stress signals in the tumour and its microenvironment. Nat Rev Cancer. 2021;21: 71-88.

6. Calfon M, Zeng H, Urano F, Till JH, Hubbard SR, Harding HP, et al. IRE1 couples endoplasmic reticulum load to secretory capacity by processing the XBP-1 mRNA. Nature. 2002;415: 92-96.

7. Chopra S, Giovanelli P, Alvarado-Vazquez PA, Alonso S, Song M, Sandoval TA, et al. IRE1 $\alpha$-XBP1 signaling in leukocytes controls prostaglandin biosynthesis and pain. Science. 2019;365(6450): eaau6499.

8. Martinon F, Chen X, Lee AH, Glimcher LH. TLR activation of the transcription factor XBP1 regulates innate immune responses in macrophages. Nat Immunol. 2011;11: 411-418.

9. Zeng L, Liu YP, Sha H, Chen H, Qi L, Smith JA. XBP-1 couples endoplasmic reticulum stress to augmented IFN- $\beta$ induction via a cis-acting enhancer in macrophages. $\mathrm{J}$ Immunol. 2010;185: 2324-2330.

10. Márquez S, Fernández JJ, Terán-Cabanillas E, Herrero C, Alonso S, Azogil A, et al. Endoplasmic reticulum stress sensor IRE1 $\alpha$ enhances IL-23 expression by human dendritic cells. Front Immunol. 2017;8: 639.

11. Mogilenko DA, Haas JT, L'homme L, Fleury S, Quemener S, Levavasseur, et al. Metabolic and innate immune cues merge into a specific inflammatory response via the UPR. Cell. 2019;177: 1201-1216.

12. Keestra-Gounder AM, Byndloss MX, Seyffert N, Young BM, Chávez-Arroyo A, Tsai AY, et al. NOD1 and NOD2 signalling links ER stress with inflammation. Nature. 2016;532: 394-397. 
medRxiv preprint doi: https://doi.org/10.1101/2022.01.26.22269752; this version posted January 28,2022 . The copyright holder for this preprint (which was not certified by peer review) is the author/funder, who has granted medRxiv a license to display the preprint in All rights reserved. perpetuity.

13. Qiu Q, Zheng Z, Chang L, Zhao YS, Tan C, Dandekar A, et al. Toll-like receptor-mediated IRE1 $\alpha$ activation as a therapeutic target for inflammatory arthritis. EMBO J. 2013;32: 2477-2490.

14. Rosen DA, Seki SM, Fernández-Castañeda A, Beiter RM, Eccles JD, Woodfolk JA, et al. Modulation of the sigma-1 receptor-IRE1 pathway is beneficial in preclinical models of inflammation and sepsis. Sci Transl Med. 2019;11(478):eaau5266.

15. Sule G, Abuaita BH, Steffes PA, Fernandes AT, Estes SK, Dobry C, et al. Endoplasmic reticulum stress sensor IRE1 $\alpha$ propels neutrophil hyperactivity in lupus. J Clin Invest. 2021;131(7):e137866.

16. Prasad, V, Suomalainen M, Jasiqi Y, Hemmi S, Hearing P, Hosie L, et al. The UPR sensor IRE1 $\alpha$ and the adenovirus E3-19K glycoprotein sustain persistent and lytic infections. Nat Commun. 2020;11: 1997.

17. Prasad V, Greber UF. The endoplasmic reticulum unfolded protein response - homeostasis, cell death and evolution in virus infections. FEMS Microbiol Rev. 2021;45: fuab016.

18. Hrincius ER, Liedmann S, Finkelstein D, Vogel P, Gansebom S, Samarasinghe AE, et al. Acute lung injury results from innate sensing of viruses by an ER stress pathway. Cell Rep. 2015;11: 1591-1603.

19. Rosa-Fernandes L, Lazari LC, Macedo da Silva J, de Morais Gomes V, Guaragna Machado RR, Ferreira dos Santos A, et al. SARS-CoV-2 activates ER stress and unfolded protein response. bioRxiv. 2021; doi: https://doi.org/10.1101/2021.06.21.449284.

20. Liu N, Jiang C, Cai P, Shen Z, Sun W, Xu H, et al. Single-cell analysis of COVID-19, sepsis, and HIV infection reveals hyperinflammatory and immunosuppressive signatures in monocytes. Cell Rep. 2021;37: 109793.

21. Blanco-Melo D, Nilsson-Payant BE, Liu WC, Uhl S, Hoagland D, Møller R, et al. Imbalanced host response to SARS-CoV-2 drives development of COVID-19. Cell. 2020;81: 1036-1045.

22. Xu X, Han M, Li T, Sun W, Wang D, Fu B, et al. Effective treatment of severe COVID-19 patients with tocilizumab. Proc Natl Acad Sci USA. 2020;117: 10970-10975.

23. Acosta-Alvear D, Zhou Y, Blais A, Tsikitis M, Lents NH, Arias C, et al. XBP1 controls diverse cell-type and condition-specific transcriptional regulatory networks. Mol Cell. 2007;27: 53-66.

24. Cubillos-Ruiz JR, Silberman PC, Rutkowski MR, Chopra S, Perales-Puchalt A, Song M, et al. ER stress sensor XBP1 controls anti-tumor immunity by disrupting dendritic cell homeostasis. Cell. 2015;161: 1527-1538. 
medRxiv preprint doi: https://doi.org/10.1101/2022.01.26.22269752; this version posted January 28,2022 . The copyright holder for this preprint (which was not certified by peer review) is the author/funder, who has granted medRxiv a license to display the preprint in All rights reserved. perpetuity.

25. Song M, Sandoval TA,Chae CS, Chopra S, Tan C, Rutkowski MR, et al. IRE1 $\alpha$-XBP1 controls $\mathrm{T}$ cell function in ovarian cancer by regulating mitochondrial activity. Nature. 2018;562: 423-428.

26. Echavarría-Consuegra L, Cook GM, Busnadiego I, Lefèvre C, Keep S, Brown K, et al. Manipulation of the unfolded protein response: A pharmacological strategy against coronavirus infection. PLoS Pathog. 2021;17(6):e1009644.

27. Nguyen LC, Yang D, Nicolaescu V, Best TJ, Gula H, Saxena D, et al. Cannabidiol inhibits SARS-CoV-2 replication through induction of the host ER stress and innate immune responses. Sci Adv. 2022 Jan 20:6110. Epub ahead of print. PMID: 35050692.

28. van der Made CI, Simons A, Schuurs-Hoeijmakers J, van den Heuvel G, Mantere T, Kersten $\mathrm{S}$, et al. Presence of genetic variants among young men with severe COVID-19. JAMA. 2020;324: 1-11.

29. Rodríguez M, Domingo E, Alonso S, Frade JG, Eiros J, Sánchez Crespo M, et al. The unfolded protein response and the phosphorylations of activating transcription factor 2 in the trans-activation of IL23A promoter produced by $\beta$-glucans. J Biol Chem. 2014;289: 22942-22957.

30. Turini ME, DuBois RN. Cyclooxygenase-2: A Therapeutic Target. Annu Rev Med. 2002;53: 35-57.

31. Codo AC, Davanzo GG, Monteiro LB, de Souza GF, Muraro SP, Virgilio-da-Silva JV, et al. Elevated glucose levels favor SARS-CoV-2 infection and monocyte response through a HIF-1 $\alpha /$ glycolysis-dependent axis. Cell Metab. 2020;32: 437-446.

32. O'Carroll SM, O'Neill LAJ. Targeting immunometabolism to treat COVID-19. Immunother Adv. 2021;1: ltab013.

33. Song R, Gao Y, Dozmorov I, Malladi V, Saha I, McDaniel MM, et al. IRF1 governs the differential interferon-stimulated gene responses in human monocytes and macrophages by regulating chromatin accessibility. Cell Rep. 2021;34: 108891.

34. Hoffmann M, Kleine-Weber H, Schroeder S, Krüger N, Herrler T, Erichsen S, et al. SARSCoV-2 cell entry depends on ACE2 and TMPRSS 2 and is blocked by a clinically proven protease inhibitor. Cell. 2020;181: 271-280.

35. Andolfo I, Russo R, Lasorsa VA, Cantalupo S, Rosato BE, Bonfiglio F, et al. Common variants at 21q22.3 locus influence $M X 1$ and TMPRSS2 gene expression and susceptibility to severe COVID-19. iScience. 2021;24: 102322.

36. Hadjadj J, Yatim N, Barnabei L, Corneau A, Boussier J, Smith N, et al. Impaired type I interferon activity and inflammatory responses in severe COVID-19 patients. Science. 2020;369: 718-724. 
medRxiv preprint doi: https://doi.org/10.1101/2022.01.26.22269752; this version posted January 28,2022 . The copyright holder for this preprint (which was not certified by peer review) is the author/funder, who has granted medRxiv a license to display the preprint in All rights reserved. perpetuity.

703

704

705

706

707

708

709

710

711

712

713

714

715

716

717

718

719

720

721

722

723

724

725

726

727

728

729

730

731

732

733

734

735

37. Karki R, Sharma BR, Tuladhar S, Williams EP, Zalduondo L, Samir P, et al. Synergism of TNF- $\alpha$ and IFN- $\gamma$ triggers inflammatory cell death, tissue damage, and mortality in SARS-CoV-2 infection and cytokine shock syndromes. Cell. 2021;184: 149-168.e17.

38. Huang KJ, Su IJ, Theron M, Wu YC, Lai SK, Liu CC, et al. An interferon- $\gamma$-related cytokine storm in SARS patients. J Med Virol. 2005;75: 185-194.

39. Broggi A, Ghosh S, Sposito B, Spreafico R, Balzarini F, Lo Cascio A, et al. Type III interferons disrupt the lung epithelial barrier upon viral recognition. Science. 2020;369: 706-712.

40. Gao DK, Salomonis N, Henderlight M, Woods C, Thakkar K, Grom AA, et al. IFN- $\gamma$ is essential for alveolar macrophage driven pulmonary inflammation in macrophage activation syndrome. JCI Insight. 2021;27: 147593.

41. Verma AK, Bauer C, Palani S, Metzger DW, Sun K. IFN- $\gamma$ drives TNF- $\alpha$ hyperproduction and lethal lung inflammation during antibiotic treatment of postinfluenza staphylococcus aureus pneumonia. J Immunol. 2021;207: 1371-1376.

42. Mimura N, Fulciniti M, Gorgun G, Tai YT, Cirstea D, Santo L, et al. Blockade of XBP1 splicing by inhibition of IRE1 $\alpha$ is a promising therapeutic option in multiple myeloma. Blood. 2012;119: 5772-5781.

43. Krawczyk CM, Holowka T, Sun J, Blagih J, Amiel E, DeBerardinis RJ, et al. Toll-like receptor-induced changes in glycolytic metabolism regulate dendritic cell activation. Blood. 2010;115: 4742-4749.

44. Xian H, Liu Y, Rundberg Nilsson A, Gatchalian R, Crother TR, Tourtellotte WG, et al. Metformin inhibition of mitochondrial ATP and DNA synthesis abrogates NLRP3 inflammasome activation and pulmonary inflammation. Immunity. 2021;54: 14631477.e11.

45. Kelly B, Tannahill GM, Murphy MP, O'Neill LA. Metformin inhibits the production of reactive oxygen species from NADH:ubiquinone oxidoreductase to limit induction of interleukin-1 $\beta$ (IL-1 $\beta$ ) and boosts interleukin-10 (IL-10) in lipopolysaccharide (LPS)activated macrophages. J Biol Chem. 2015;290: 20348-20359.

46. Baselski VS, Wunderink RG. Bronchoscopic diagnosis of pneumonia. Clin Microbiol Rev. 1994;7: 533-558.

47. Shin YM, Oh YM, Kim MN. Usefulness of quantitative endotracheal aspirate cultures in intensive care unit patients with suspected pneumonia. J Korean Med Sci. 2011;26: 865869. 
medRxiv preprint doi: https://doi.org/10.1101/2022.01.26.22269752; this version posted January 28,2022 . The copyright holder for this preprint (which was not certified by peer review) is the author/funder, who has granted medRxiv a license to display the preprint in All rights reserved. perpetuity.

48. Pickens C, Wunderink RG, Qi C, Mopuru H, Donnelly H, Powell K, et al. A multiplex polymerase chain reaction assay for antibiotic stewardship in suspected pneumonia. Diagn Microbiol Infect Dis. 2020;98: 115179.

49. Zhou Z, Ren L, Zhang L, Zhong J, Xiao Y, Jia Z, et al. Heightened innate immune responses in the respiratory tract of COVID-19 patients. Cell Host Microbe. 2020;27: 883-890.

50. Liao M, Liu Y, Yuan J, Wen Y, Xu G, Zhao J, et al. Single-cell landscape of bronchoalveolar immiune cells in patients with COVID-19. Nat. Med. 2020;26: 842844.

51. Szabo PA, Dogra P, Gray JI, Wells SB, Connors TJ, Weisberg SP, et al. Developmental regulation of effector and resident memory $\mathrm{T}$ cell generation during pediatric viral respiratory tract infection. J Immunol. 2018;201: 432-439.

52. Connors TJ, Baird JS, Yopes MC, Zens KD, Pethe K, Ravindranath TM, et al. Developmental regulation of effector and resident memory $\mathrm{T}$ cell generation during pediatric viral respiratory tract Infection. J Immunol. 2018;201: 432-439.

53. Connors TJ, Ravindranath TM, Bickham KL, Gordon CL, Zhang F, Levin B, et al. Airway $\mathrm{CD} 8(+) \mathrm{T}$ cells are associated with lung injury during infant viral respiratory tract infection. Am J Respir Cell Mol Biol. 2016;54: 822-830.

54. Sarma A, Christenson SA, Byrne A, Mick E, Pisco AO, DeVoe C, et al. Tracheal aspirate RNA sequencing identifies distinct immunological features of COVID-19 ARDS. Nat Commun. 2021;12:5152.

55. Sinha P, Matthay MA, Calfee CS. Is a "Cytokine Storm" relevant to COVID-19? JAMA Intern Med. 2020;180:1152-1154.

56. Kox M, Waalders NJB, Kooistra EJ, Gerretsen J, Pickkers P. Cytokine levels in critically Ill patients with COVID-19 and other conditions. JAMA. 2020;324:1565-1567.

57. Lenze EJ, Mattar C, Zorumski CF, Stevens A, Schweiger J, Nicol GE, et al. Fluvoxamine vs placebo and clinical deterioration in outpatients with symptomatic COVID-19: A randomized clinical trial. JAMA. 2020;324: 2292-2300.

58. Reis G, dos Santos Moreira-Silva EA, Medeiros Silva DC, Thabane L, Cruz Milagres A, Santiago Ferreira T, et al. Effect of early treatment with fluvoxamine on risk of emergency care and hospitalisation among patients with COVID-19: the TOGETHER randomised, platform clinical trial. Lancet Glob Health 2022 Jan;10(1):e42-e51.

59. Shi S, Blumenthal A, Hickey CM, Gandotra S, Levy D, Ehrt S. Expression of many immunologically important genes in Mycobacterium tuberculosis-infected macrophages is independent of both TLR 2 and TLR4 but dependent on IFN- $\alpha \beta$ receptor and STAT1. J Immunol. 2005;175: 3318-3328. 
medRxiv preprint doi: https://doi.org/10.1101/2022.01.26.22269752; this version posted January 28,2022 . The copyright holder for this preprint (which was not certified by peer review) is the author/funder, who has granted medRxiv a license to display the preprint in All rights reserved. perpetuity.

60. Michelucci A, Cordes T, Ghelfi J, Pailot A, Reiling N, Goldmann O, et al. Immuneresponsive gene 1 protein links metabolism to immunity by catalyzing itaconic acid production. Proc Natl Acad Sci USA. 2013;110: 7820-7825.

61. Hooftman A, Angiari S, Hester S, Corcoran SE, Runtsch MC, Ling C, et al. The immunomodulatory metabolite itaconate modifies NLRP3 and inhibits inflammasome activation. Cell Metab. 2020;32: 468-478.

62. Giamarellos-Bourboulis EJ, Netea MG, Rovina N, Akinosoglou K, Antoniadou A, Antonakos N, et al. Complex immune dysregulation in COVID-19 patients with severe respiratory failure. Cell Host Microbe. 2020;27: 992-1000.e3.

63. Rappe JCF, Finsterbusch K, Crotta S, Mack M, Priestnall SL, Wack A. A TLR7 antagonist restricts interferon-dependent and -independent immunopathology in a mouse model of severe influenza. J Exp Med. 2021;218: e20201631.

64. Li Y, Chen M, Cao H, Zhu Y, Zheng J, Zhou H. Extraordinary GU-rich single-strand RNA identified from SARS coronavirus contributes an excessive innate immune response. Microbes Infect. 2013;15: 88-95.

65. Campbell GR, To RK, Hanna J, Spector SA. SARS-CoV-2, SARS-CoV-1, and HIV-1 derived ssRNA sequences activate the NLRP3 inflammasome in human macrophages through a non-classical pathway. iScience. 2021;24: 102295.

66 Fallerini C, Daga S, Mantovani S, Benetti E, Picchiotti N, Francisci D, et al. Association of Toll-like receptor 7 variants with life-threatening COVID-19 disease in males: findings from a nested case-control study. Elife. 2021;10: e67569.

67. Zhang Q, Bastard P, Liu Z, Le Pen J, Moncada-Velez M, Chen J, et al. Inborn errors of type I IFN immunity in patients with life-threatening COVID-19. Science. 2020;370: eabd4570.

68. Ito T, Amakawa R, Kaisho T, Hemmi H, Tajima K, Uehira K, et al. Interferon- $\alpha$ and interleukin-12 are induced differentially by Toll-like receptor 7 ligands in human blood dendritic cell subsets. J Exp Med. 2002;195: 1507-1512.

69. Olson GS, Murray TA, Jahn AN, Mai D, Diercks AH, Gold ES, et al. Type I interferon decreases macrophage energy metabolism during mycobacterial infection. Cell Rep. 2021;35: 109195 .

70. Thwe PM, Fritz DI, Snyder JP, Smith PR, Curtis KD, O'Donnell A, et al. Syk-dependent glycolytic reprogramming in dendritic cells regulates IL-1 $\beta$ production to $\beta$-glucan ligands in a TLR-independent manner. J Leukoc Biol. 2019;106: 1325-1335.

71. Fan E, Del Sorbo L, Goligher EC, Hodgson CL, Munshi L, Walkey AJ, et al. An Official American Thoracic Society/European Society of Intensive Care Medicine/Society of 
medRxiv preprint doi: https://doi.org/10.1101/2022.01.26.22269752; this version posted January $28,2022$. The copyright holder for this preprint (which was not certified by peer review) is the author/funder, who has granted medRxiv a license to display the preprint in All rights reserved. No reuse allowed without permission.

Critical Care Medicine Clinical Practice Guideline: Mechanical Ventilation in Adult Patients with Acute Respiratory Distress Syndrome. Am J Respir Crit Care Med. 2017;195: 1253-1263. 
medRxiv preprint doi: https://doi.org/10.1101/2022.01.26.22269752; this version posted January 28,2022 . The copyright holder for this preprint (which was not certified by peer review) is the author/funder, who has granted medRxiv a license to display the preprint in perpetuity.

All rights reserved. No reuse allowed without permission.

A

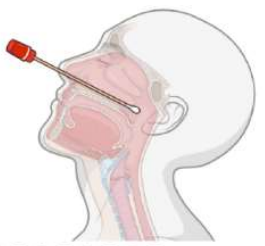

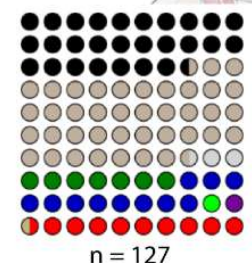

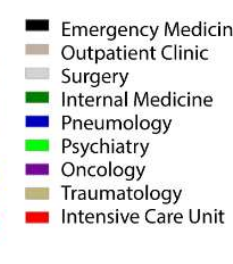

C
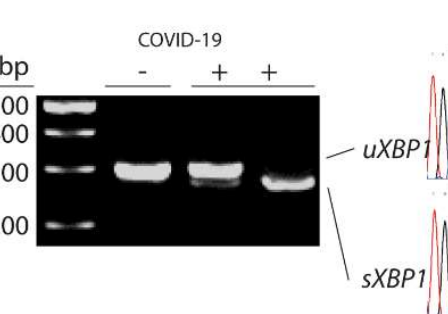

No SPLICING Homologous to NM_005080.4

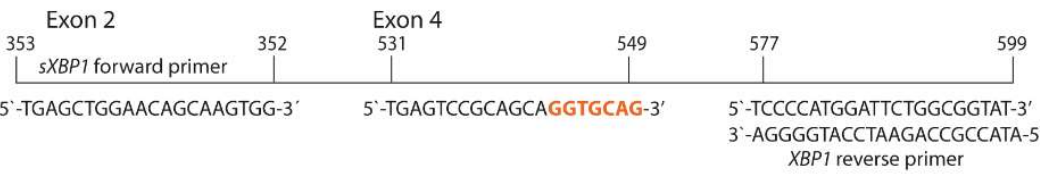

D
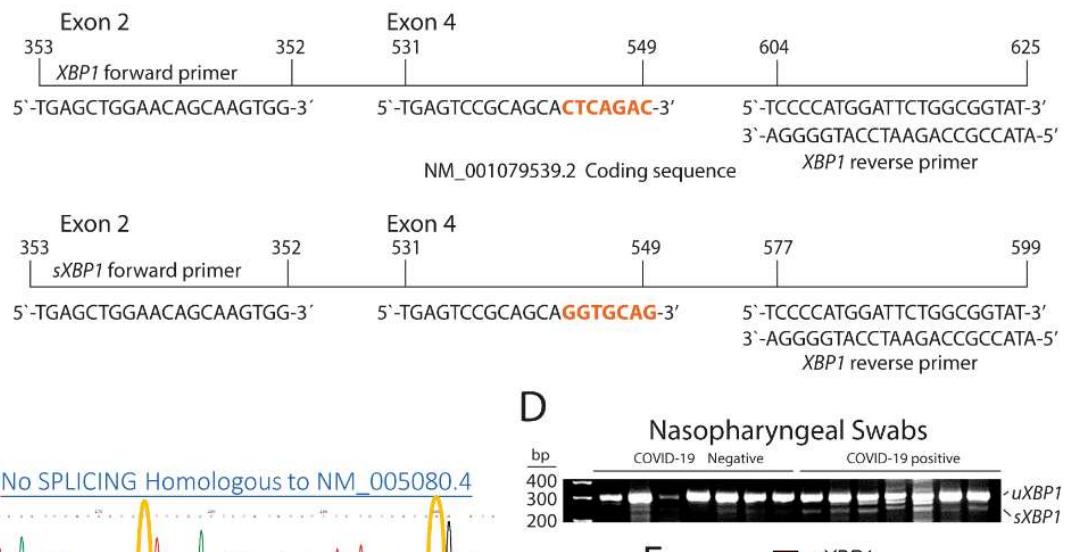

812

813

814

815

816

817

818

819

820

821

822

823

824

825

826

827
B NM_005080.4 Coding sequence

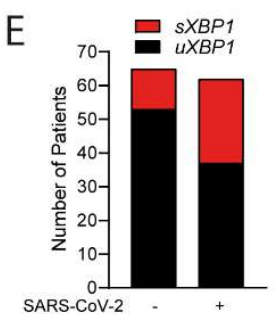

I
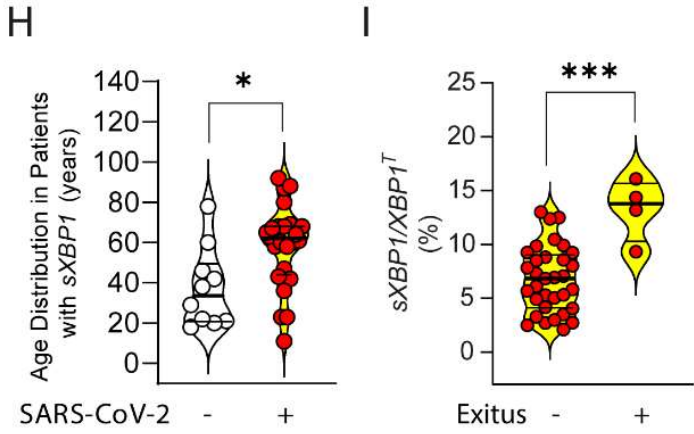
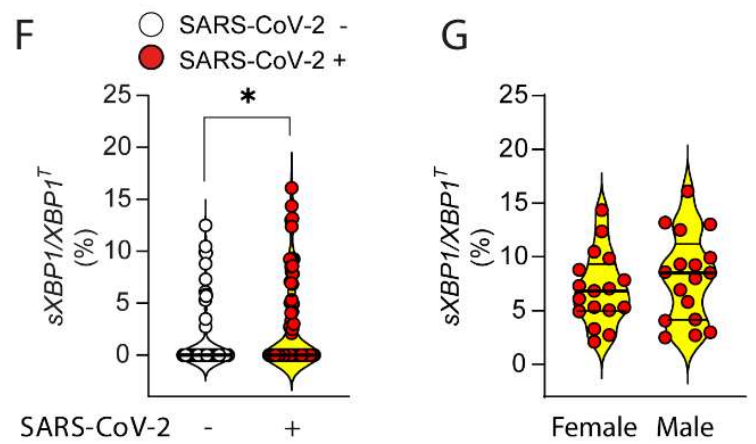

Fig 1. Sequences of XBP1 mRNA transcripts and analysis of RT-PCR products in nasopharyngeal samples. (A) Medical departments involved in the obtention of nasopharyngeal swabs. (B) The splicing of 26 nucleotides in NM_005080.4 sequence generates the 531-549 sequence in NM_001079539.2. The position of primers, including the reverse primer spanning the spliced sequence is shown. (C) Agarose gel electrophoresis and sequencing of the amplicons obtained by RT-PCR with XBP1 primers showing the migration of the spliced $(s X B P 1)$ and unspliced products $(u X B P 1)$. (D) The electrophoretic pattern of $X B P 1$ in a series of samples from COVID-19 negative and positive patients is shown. The presence of three bands in some cases is due to the formation of heteroduplexes. (E) Distribution of patients according to the presence or absence of $s X B P 1$ in SARS-CoV-2 negative and positive patients. (F) Quantitation of $S X B P 1$ versus total $X B P 1\left(X B P 1^{T}\right)$ in COVID-19 positive and negative samples. $(\mathrm{G})$ Quantitation of $s X B P 1$ versus total $X B P 1$ in male and female SARS-CoV-2 positive patients. (H) Age distribution of patients with $s X B P 1$. (I) Quantitation of $s X B P 1$ versus total $X B P 1$ in SARS-CoV-2 positive according to the outcome. ${ }^{*} \mathrm{p}<0.05, * * * \mathrm{p}<0.005$, paired or unpaired (two-tail) $t$ test. 
medRxiv preprint doi: https://doi.org/10.1101/2022.01.26.22269752; this version posted January 28, 2022. The copyright holder for this preprint (which was not certified by peer review) is the author/funder, who has granted medRxiv a license to display the preprint in All rights reserved. No reuse allowed without permission.

A sample Collection $\quad B$

B
\begin{tabular}{|l|c|c|c|c|}
\hline \multicolumn{1}{|c|}{ Pneumonia } & Age (mean \pm SEM) & $\begin{array}{c}\text { sXBP1 } \\
\% \text { mortality }\end{array}$ & $\begin{array}{c}\text { uXBP1 } \\
\% \text { mortality }\end{array}$ & Steroid treatment \\
\hline O COVID-19 RT-PCR + & $69.90 \pm 2.006$ & 22.72 & 22.22 & Mandatory \\
\hline O COVID-19 RT-PCR - & $70.92 \pm 2.995$ & 33.33 & 22.66 & Mandatory \\
\hline O Non-COVID & $75.59 \pm 1.561$ & 16.66 & 40.33 & Occasional \\
\hline
\end{tabular}

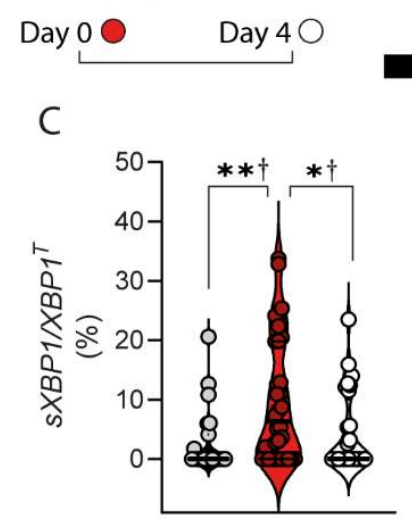

Non-COVID infection

D

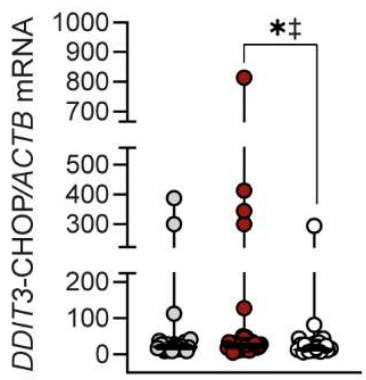

E
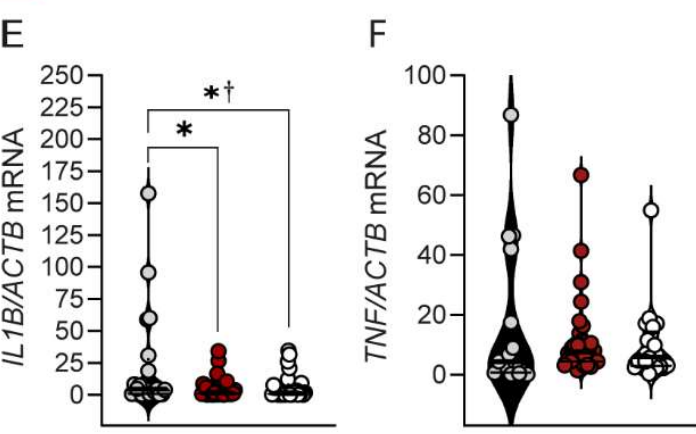

G
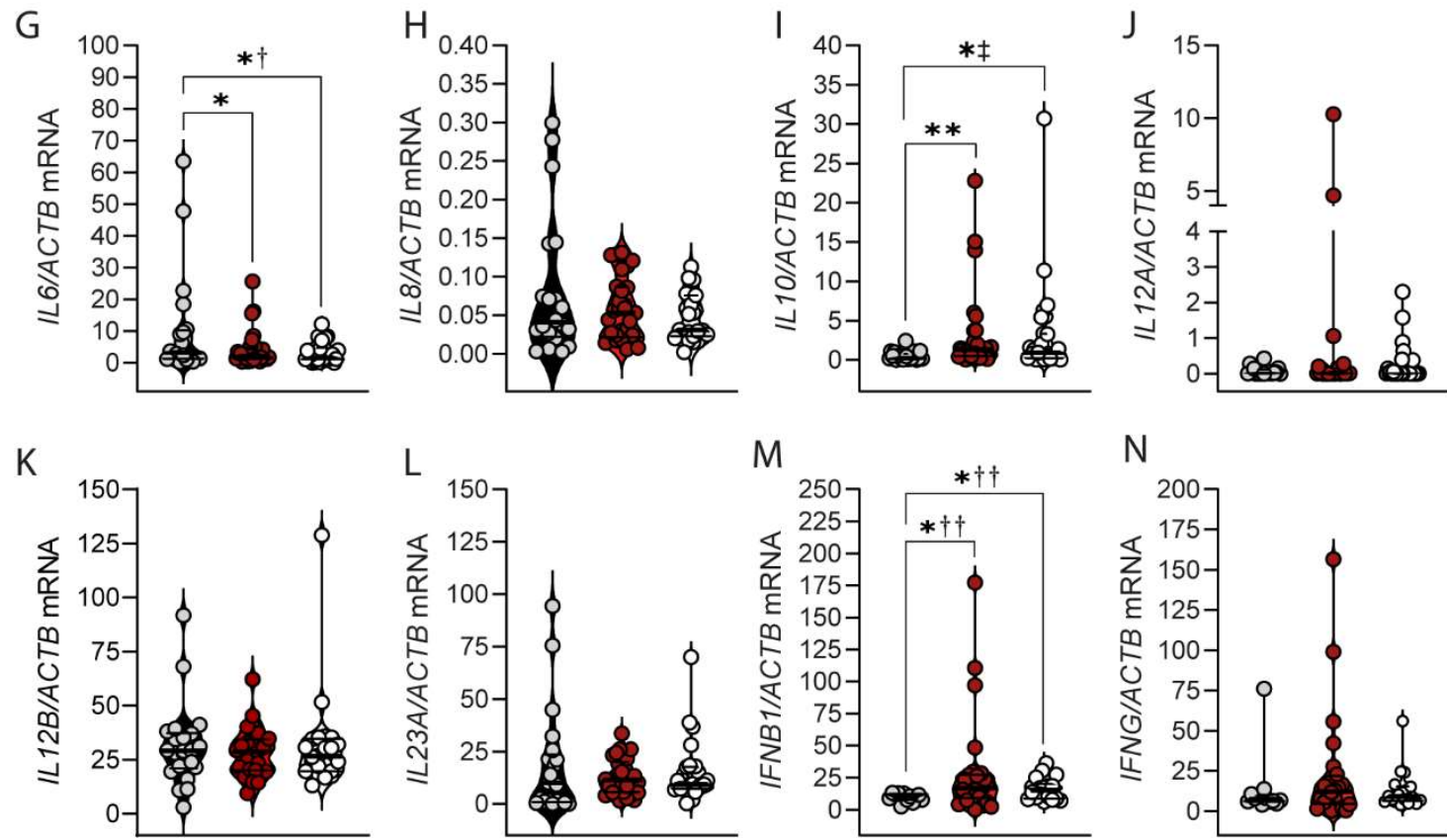

Fig 2. Expression of the mRNA of XBP1, DDIT3/CHOP, and cytokines in BAAs of patients under mechanical ventilation in ICU. (A) Scheme of sample collection. (B) Stratification of patients according to non-COVID-19, active COVID-19, and non-active COVID-19 infection. (C) $s X B P 1$ expression in the different cohorts. Results are expressed as mean \pm SEM. †Ordinary one-way ANOVA with the Tukey's multiple comparisons test. $* \mathrm{p}<$ 0.05 . $* * * \mathrm{p}<0.005$. (D) Expression of the mRNA de DDIT3/CHOP. ¥Kruskal-Wallis $U$ test. (E-N) Expression of the mRNA encoding IL1B, TNF, IL6, IL8, IL10, IL12A, IL12B, IL23A, $I F N B 1$, and IFNG in BAAs. Data are presented as mean \pm SEM. ${ }^{*} p<0.05,{ }^{* *} p<0.01$, $* * * p<0.005$. †Ordinary one-way ANOVA. $¥$ Kruskal-Wallis $U$ test. $\dagger \dagger W e l c h$ and BrownForsythe ANOVA test. 
medRxiv preprint doi: https://doi.org/10.1101/2022.01.26.22269752; this version posted January 28,2022 . The copyright holder for this preprint (which was not certified by peer review) is the author/funder, who has granted medRxiv a license to display the preprint in All rights reserved. No reuse allowed without permission.

SARS-CoV-2 + SARS-CoV-2 -
B

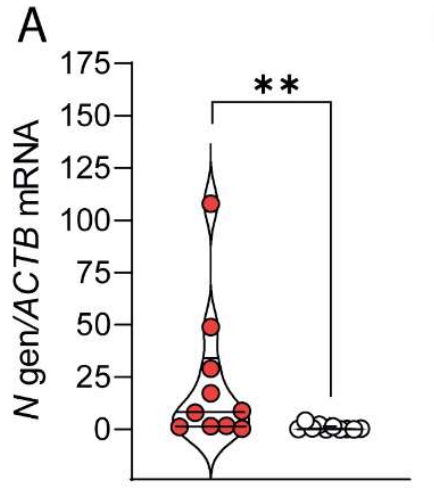

D

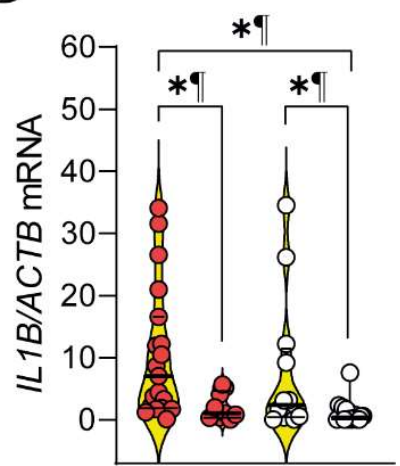

$G$

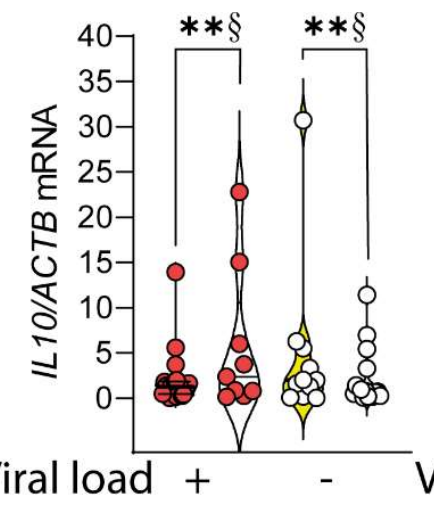

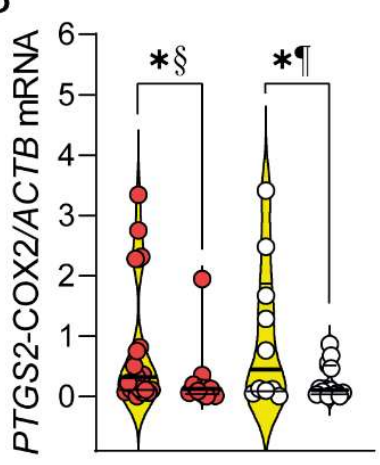

$\mathrm{E}$

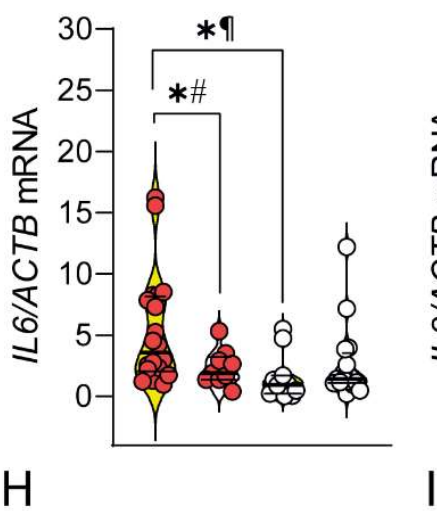

C

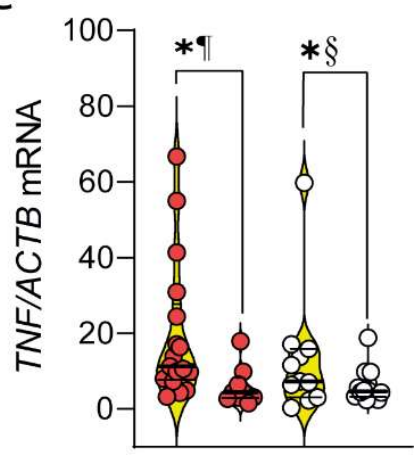

$\mathrm{F}$

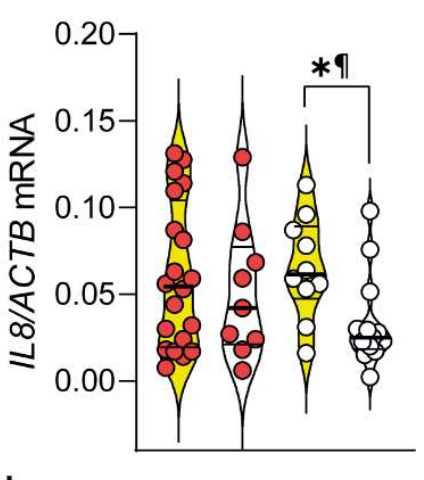

80
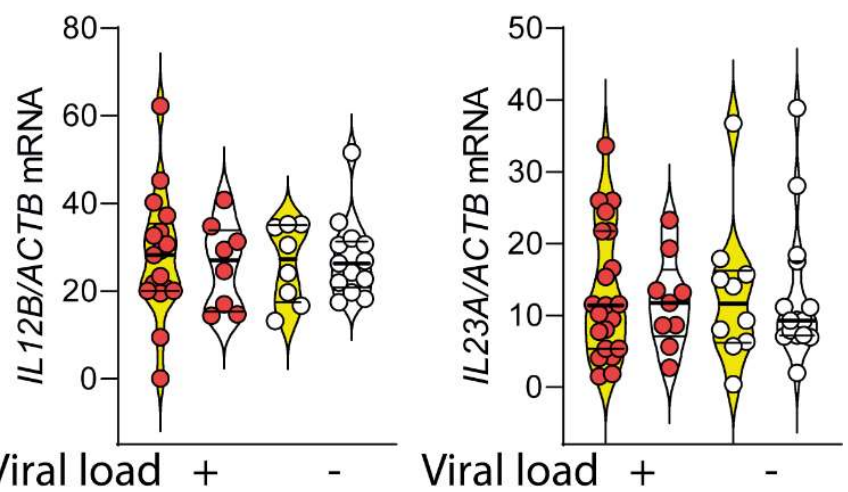

Fig 3. Association of $s X B P 1$ splicing and viral replication with cytokine expression in

BAAs. (A) Viral load in samples obtained at the time of SARS-CoV-2 positive and negative tests. Data are presented as mean \pm SEM. ${ }^{* *} \mathrm{p}<0.01$. Unpaired two-tailed Student's $t$ test. (BI) Patients were stratified in cohorts according to the presence of $S X B P 1$ and the presence or absence of viral load as deemed from RT-PCR test for SARS-CoV-2 infection. The mRNA of PTGS2 and various cytokines was assayed in the extracted RNA and the statistical significance of the results was assayed using ordinary one-way ANOVA with Tukey's post-hoc multiple comparison test. Data are presented as mean \pm SEM. ${ }^{*} \mathrm{p}<0.05$, ${ }^{* *} \mathrm{p}<0.01$, ${ }^{* * *} \mathrm{p}<0.005$. §Onesample Wilkoxon signed rank test. \Unpaired (two-tail) $t$ test. \#Welch`s test. 
medRxiv preprint doi: https://doi.org/10.1101/2022.01.26.22269752; this version posted January 28, 2022. The copyright holder for this preprint (which was not certified by peer review) is the author/funder, who has granted medRxiv a license to display the preprint in All rights reserved. No reuse allowed without permission.

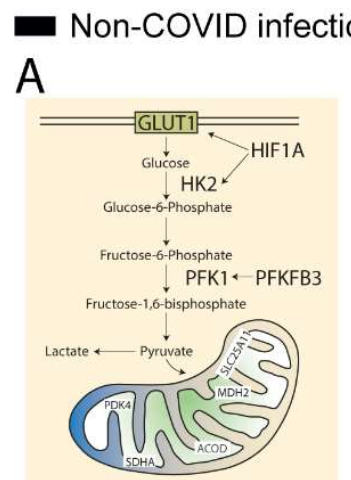

D

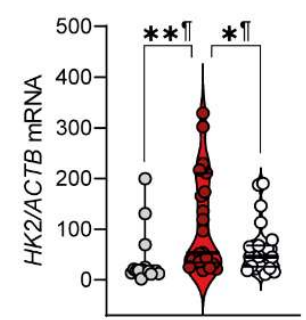

\section{G}

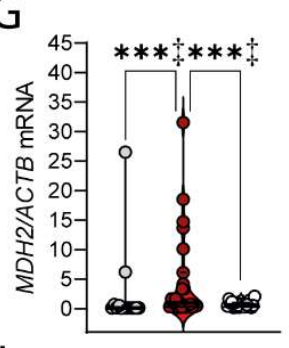

J

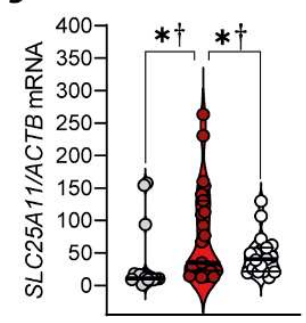

B

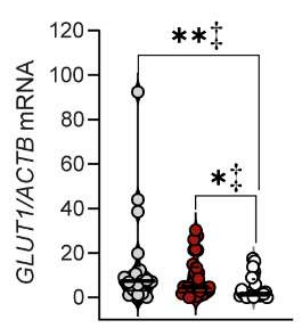

E

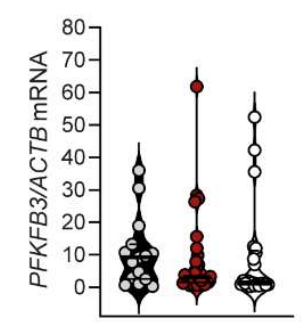

$\mathrm{H}$

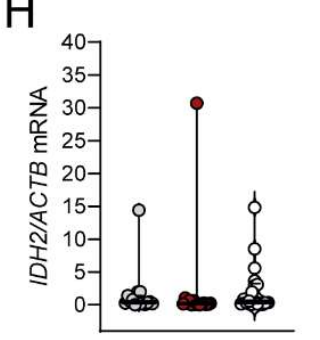

K

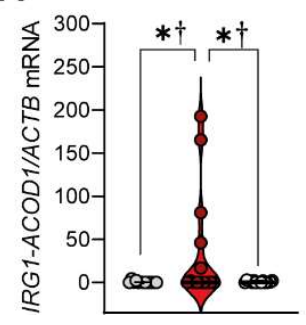

C

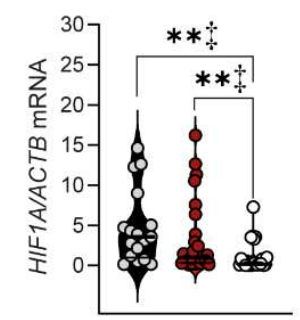

F

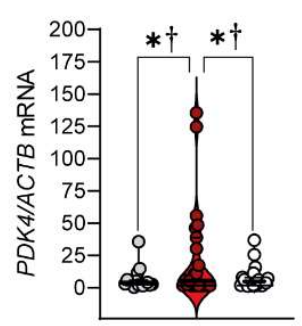

I

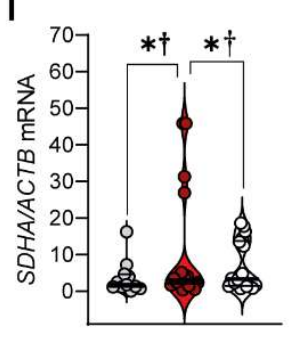

Fig 4. Expression of enzymes involved in glycolysis and mitochondrial proteins. (A) Diagram of glycolytic and mitochondrial proteins assayed in BAAs. (B-K) BAAs of patients with controlled respiration were used for RNA extraction and RT-PCR assay of mRNA expression of genes encoding for proteins involved in glycolysis, response to hypoxia, and mitochondrial function. GLUT1, glucose transporter 1. HIF 1A, hypoxia-inducible factor $1 \alpha$. HK2, hexokinase 2. PFKB3, 6-phosphofructo-2-kinase/fructose-2,6-biphosphatase. PDK4, pyruvate dehydrogenase kinase. $M D H 2$, malate dehydrogenase 2. IDH2, isocitrate dehydrogenase 2. SDHA, succinate dehydrogenase protein subunit A. SLC25A11, mitocondrial 2-oxoglutarate-malate carrier. IRG1-ACOD1, immunoresponsive gene 1-aconitate decarboxylase. Data are presented as mean \pm SEM. ${ }^{*} \mathrm{p}<0.05,{ }^{* *} \mathrm{p}<0.01,{ }^{* * *} \mathrm{p}<0.005$. $\ddagger$ Kruskal-Wallis $U$ test. $\dagger$ Ordinary one-way ANOVA. $\uparrow$ Paired or unpaired (two-tail) $t$ test. 
medRxiv preprint doi: https://doi.org/10.1101/2022.01.26.22269752; this version posted January 28, 2022. The copyright holder for this preprint (which was not certified by peer review) is the author/funder, who has granted medRxiv a license to display the preprint in All rights reserved. No reuse allowed without permission.

Non-SARS-CoV-2 infection SARS-CoV-2 + $\bigcirc$ SARS-CoV-2 -

A

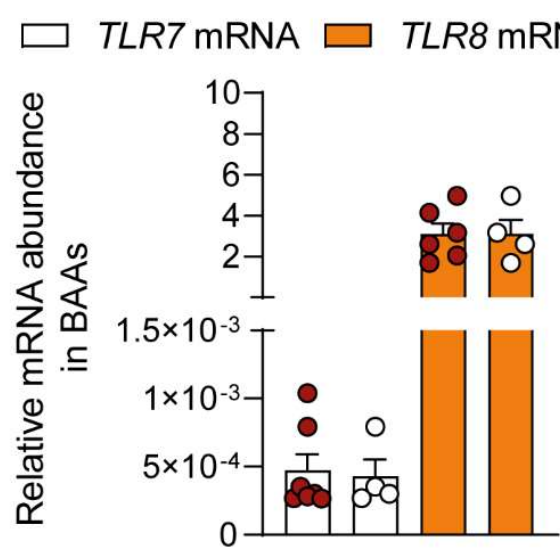

$\mathrm{B}$

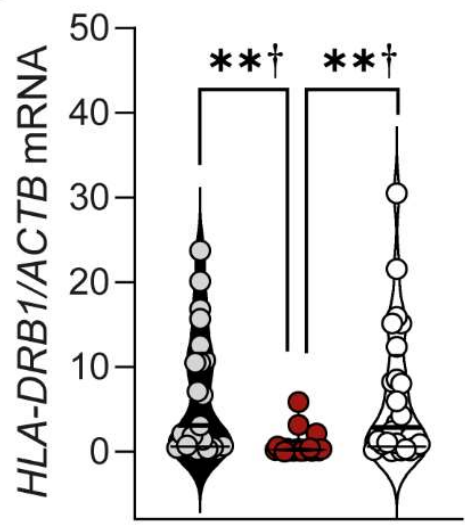

C

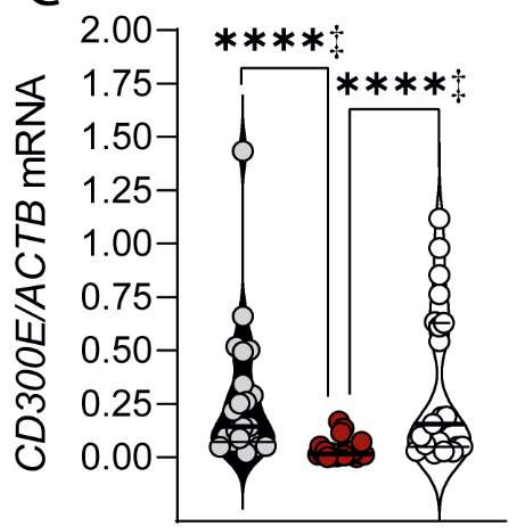

$\mathrm{F}$

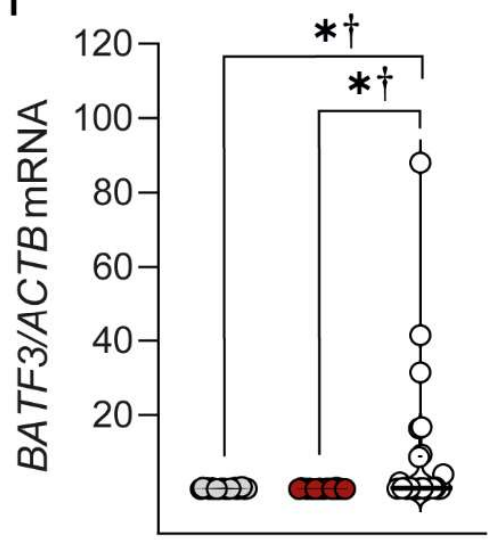

D

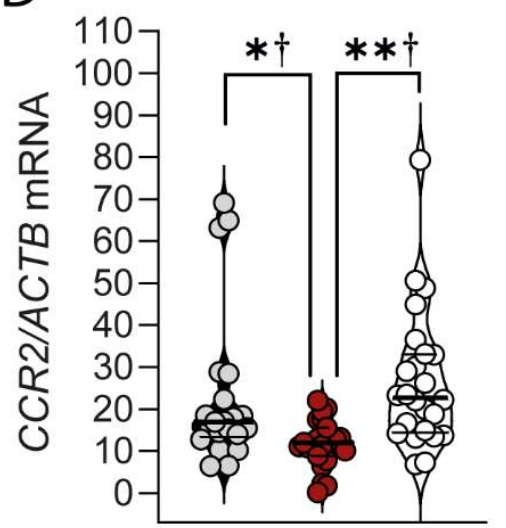

G

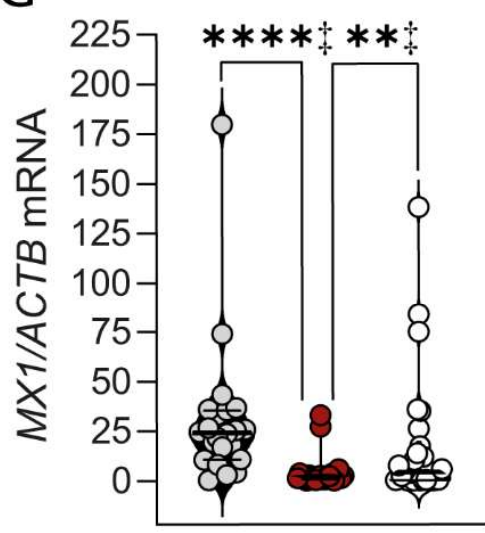

J
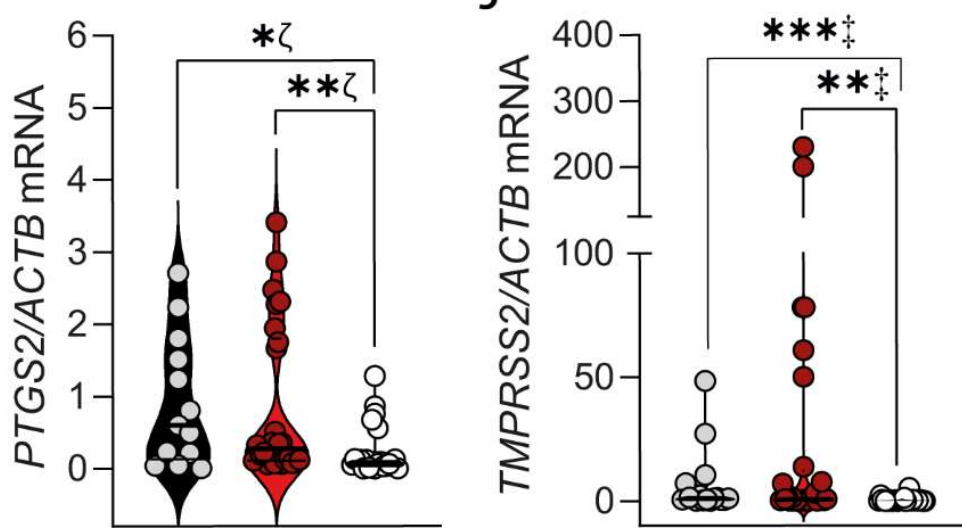

E

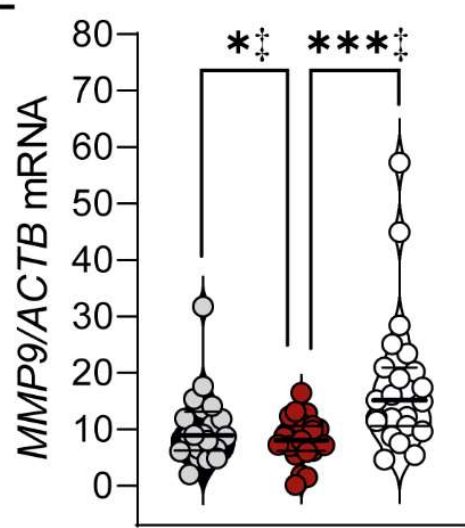

$\mathrm{H}$

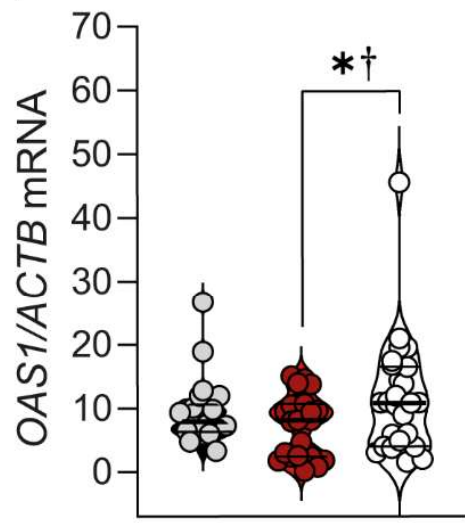


medRxiv preprint doi: https://doi.org/10.1101/2022.01.26.22269752; this version posted January $28,2022$. The copyright holder for this preprint (which was not certified by peer review) is the author/funder, who has granted medRxiv a license to display the preprint in All rights reserved. No reuse allowed without permission.

934 Fig 5. Expression of genes involved in monocytic-lineage differentiation in BAAs. (A)

935 Expression of the mRNA encoding the receptors TLR7 and TLR8 in patients with active

936 SARS-CoV-2 infection and after negative tests. (B-F) Expression of monocyte-differentiation 937 markers in BAAs of non-COVID-19, COVID-19, and post-COVID-19 infection. (G-H)

938 Expression of the ISG $M X 1$ and OAS1 mRNA. (I) Expression of the mRNA encoding $939 P T G S 2 / \mathrm{COX} 2$. (J) Expression of the mRNA encoding the transmembrane serine protease $940 T M P R S S 2$. Data are presented as mean \pm SEM. $* \mathrm{p}<0.05, * * \mathrm{p}<0.01, * * * \mathrm{p}<0.005$. $\dagger$ Ordinary 941 one-way ANOVA. ‡Kruskal-Wallis $U$ test. $\zeta$ Holm-Sidak`s multiple comparison test. 
medRxiv preprint doi: https://doi.org/10.1101/2022.01.26.22269752; this version posted January 28, 2022. The copyright holder for this preprint (which was not certified by peer review) is the author/funder, who has granted medRxiv a license to display the preprint in perpetuity.

All rights reserved. No reuse allowed without permission.

A

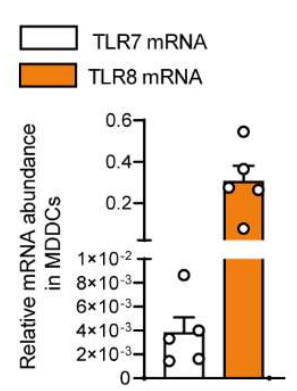

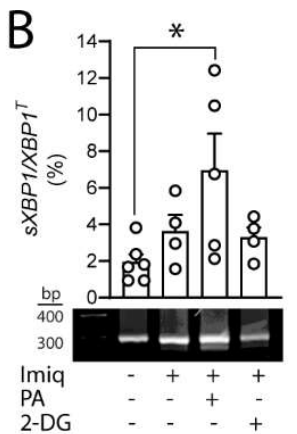

$\mathrm{H}$

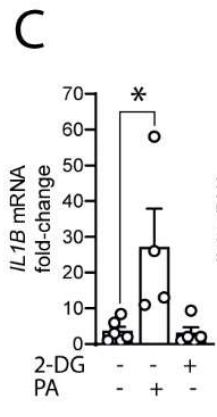

D

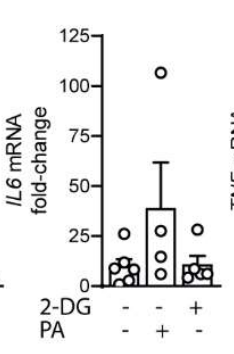

$\mathrm{E}$

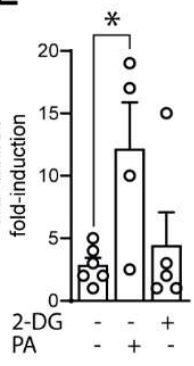

$\mathrm{F}$

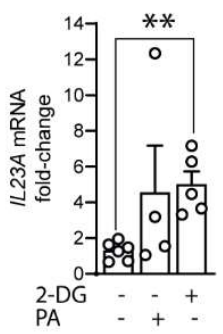

G
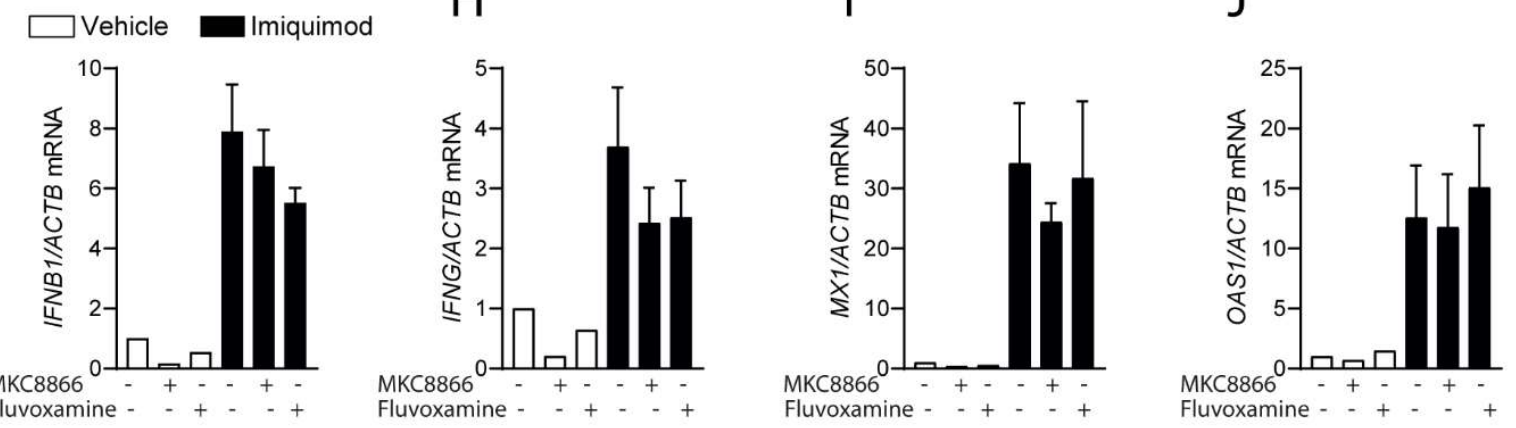

$\mathrm{K}$

$\mathrm{L}$

$\mathrm{M}$

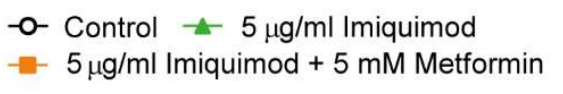

- - Control $\rightarrow-1 \mu \mathrm{g} / \mathrm{ml}$ Poly(l:C)

$-5 \mu \mathrm{g} / \mathrm{ml}$ Imiquimod
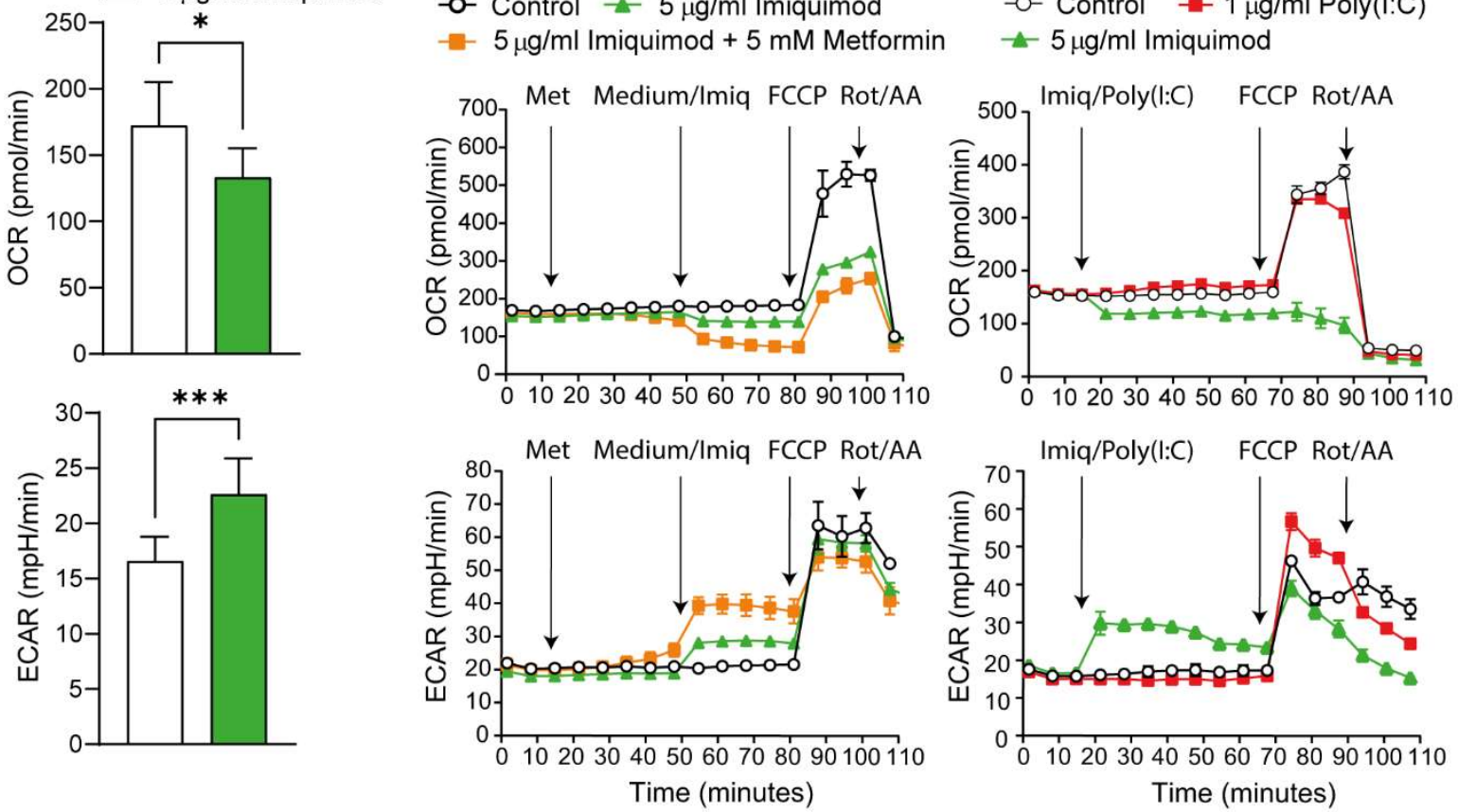

Fig 6. Expression of TLR7 and TLR8 receptors in MDDCs and response to the TLR7 agonist imiquimod. (A) Expression of the mRNA encoding TLR7 and TLR8 in MDDCs. (B) Effect of $5 \mu \mathrm{g} / \mathrm{ml}$ imiquimod on $s X B P 1$ in the presence and absence of $0.5 \mathrm{mM}$ palmitate (PA) and $10 \mathrm{mM}$ 2-deoxyglucose (2-DG). MDDCs were incubated for one hour in the presence of the indicated additions and then stimulated with imiquimod for 1 hour. At the end of this time, the RNA was extracted and used for the assay of $s X B P 1$. (C-F) Effect of imiquimod on the expression of the mRNA encoding $I L 1 B, T N F, I L 6$, and IL23A. The stimulation with 
medRxiv preprint doi: https://doi.org/10.1101/2022.01.26.22269752; this version posted January 28, 2022. The copyright holder for this preprint (which was not certified by peer review) is the author/funder, who has granted medRxiv a license to display the preprint in All rights reserved. No reuse allowed without permission.

951 imiquimod was maintained for four hours before RNA extraction. Data are presented as mean

$952 \pm$ SEM. $* \mathrm{p}<0.05, * * \mathrm{p}<0.01$. (G-J) Effect of MKC8866 and fluvoxamine on the expression

953 of the mRNA encoding IFNB1, IFNG, MX1, and OAS1. MDDCs were preincubated with 10

$954 \mu \mathrm{M}$ MKC8866 and $20 \mu \mathrm{M}$ fluvoxamine for one hour and then stimulated with $5 \mu \mathrm{g} / \mathrm{ml}$

955 imiquimod for 4 hours. At the end of this time, the RNA was extracted and used for mRNA

956 assay. (K) Effect of imiquimod on $\mathrm{O}_{2}$ consumption rate (OCR) and glycolysis assayed as

957 extracellular acidification rate (ECAR). Data are presented as mean $\pm \mathrm{SEM} .{ }^{*} \mathrm{p}<0.05, * * * \mathrm{p}<$

958 0.005, paired, (two-tail) Student's $t$ test. (L) Seahorse real-time metabolic analysis of one

959 experiment where MDDCs were stimulated with imiquimod and then treated with $2 \mu \mathrm{M} \mathrm{FCCP}$

960 (an uncoupler of oxidative phosphorylation) to estimate maximal respiratory rate, and the

961 combination $0.5 \mu \mathrm{M}$ rotenone/antimycin (Rot/AA) to inhibit complex I and complex III of the

962 mitochondrial electron transport chain. Where indicated, metformin was used to inhibit

963 complex I activity. (M) MDDCs were treated with imiquimod or with poly(I:C) to show the

964 effect of a TLR3 agonist. 
medRxiv preprint doi: https://doi.org/10.1101/2022.01.26.22269752; this version posted January 28, 2022. The copyright holder for this preprint (which was not certified by peer review) is the author/funder, who has granted medRxiv a license to display the preprint in perpetuity.

All rights reserved. No reuse allowed without permission.

A $\quad$ B

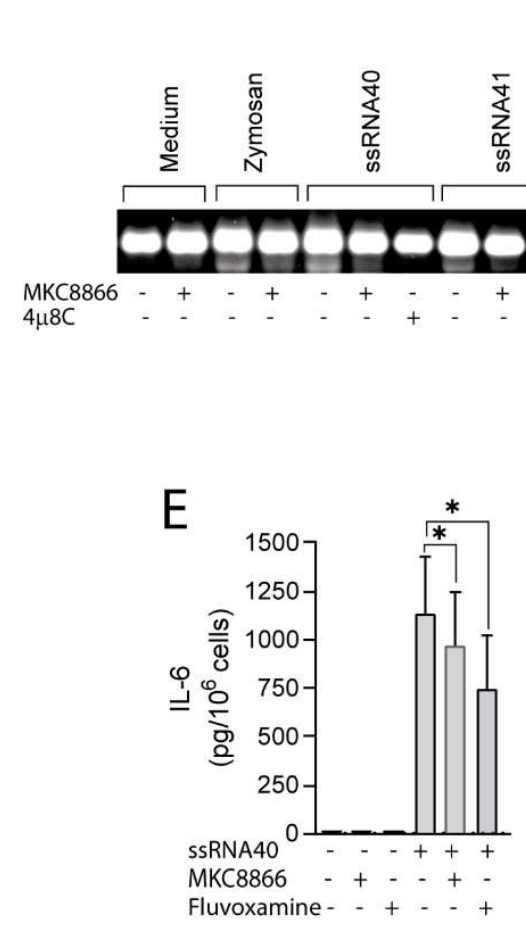

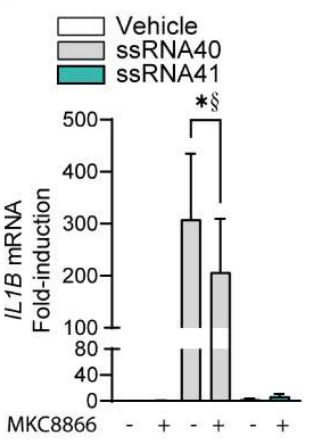

C

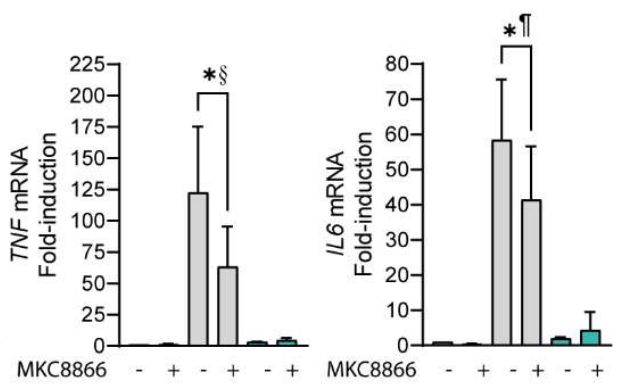

D

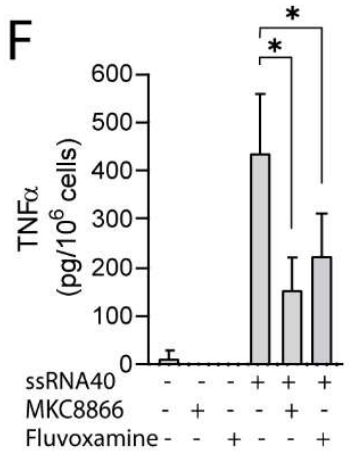

J

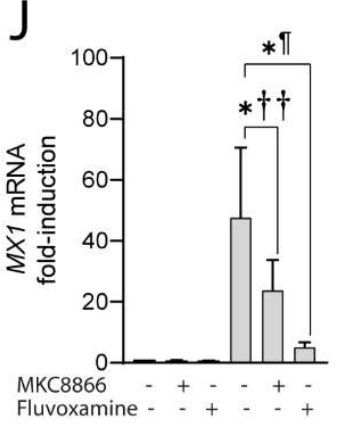

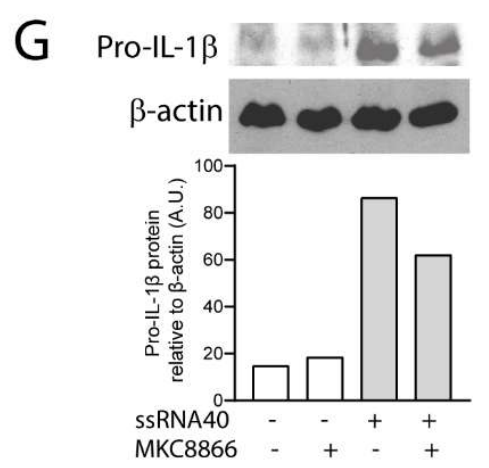
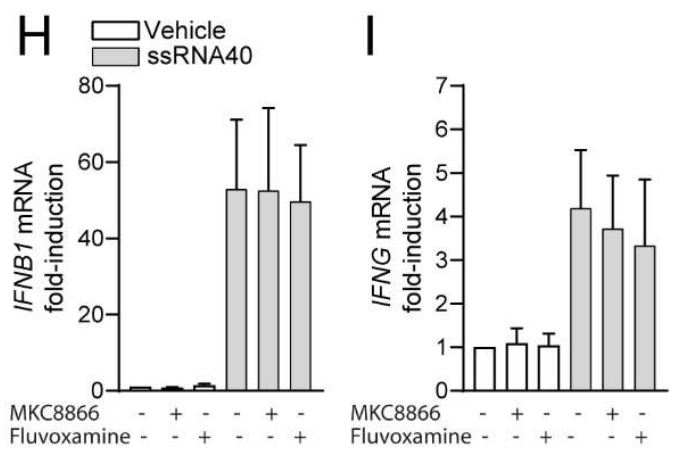

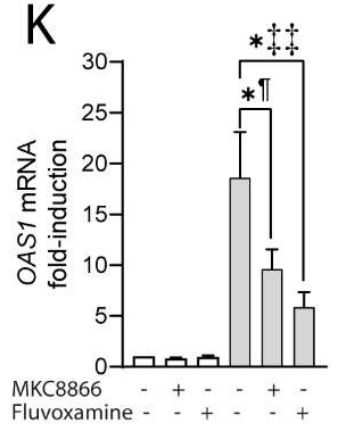

$\mathrm{N}$

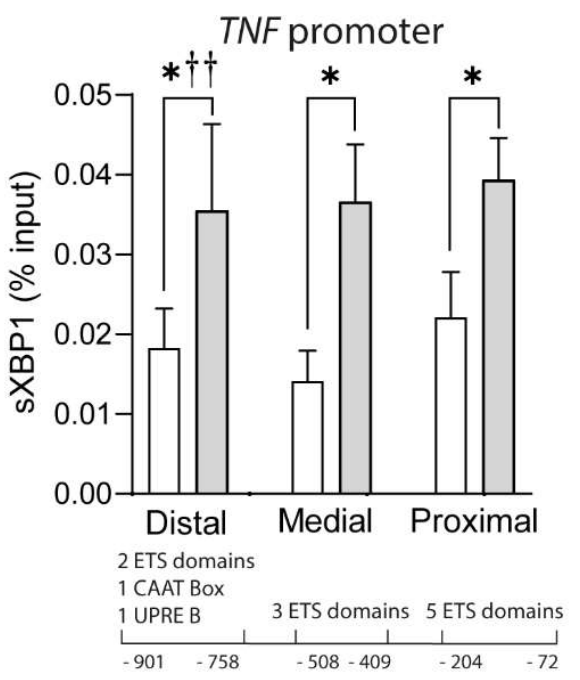

IL6 promoter
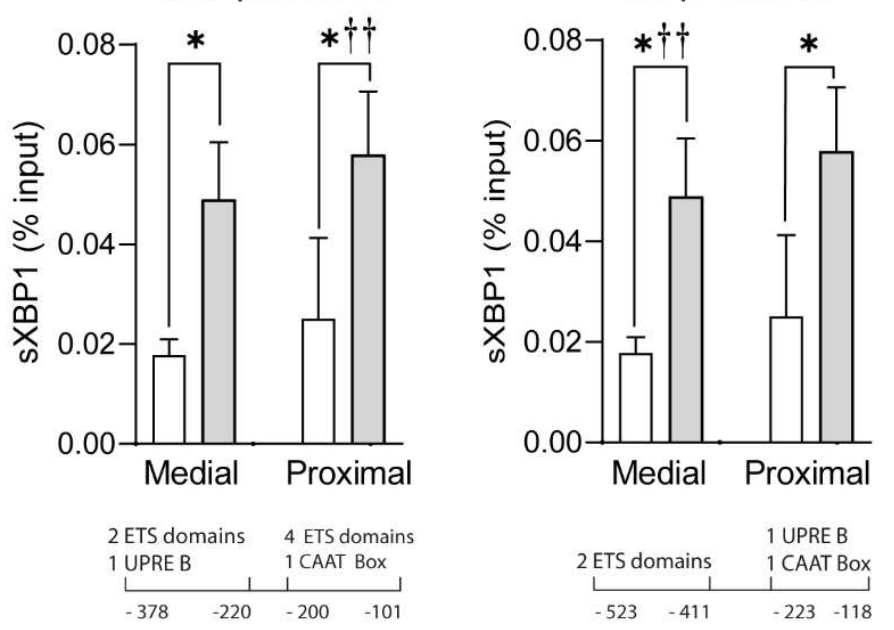
medRxiv preprint doi: https://doi.org/10.1101/2022.01.26.22269752; this version posted January 28,2022 . The copyright holder for this preprint (which was not certified by peer review) is the author/funder, who has granted medRxiv a license to display the preprint in All rights reserved. No reuse allowed without permission.

Fig 7. Effect of the TLR8 agonist ssRNA40 on MDDCs. (A) Effect of ssRNA40 and IRE1 $\alpha$ RNase inhibitors on $s X B P 1$. The RNA was collected after one hour of incubation with $10 \mu \mathrm{M}$ MKC 8866 or $20 \mu \mathrm{M} 4 \mu 8 \mathrm{C}$ and one hour of stimulation with $2 \mu \mathrm{g} / \mathrm{ml}$ of either ssRNA40 or ssRNA41 and used for the assay of $u X B P 1$ and $s X B P 1$. (B-D) Effect of $10 \mu \mathrm{M}$ MKC8866 on the mRNA expression of $I L 1 B, T N F$, and IL6 mRNA. MDDCs were maintained for one hour in the presence of MKC8866 and then stimulated with ssRNA40 or ssRNA41 for 4 hours, prior to the extraction of the RNA for cytokine assays. Data are presented as mean \pm SEM. ${ }^{*} p<$ $0.05, * * p<0.01$. §Wilcoxon matched pairs signed rank test. $\llbracket$ Paired $t$ test two-ways. (E and F) Effect of MKC8866 on the expression of IL-6 and TNF $\alpha$ protein. MDDCs were preincubated with MKC8866 for one hour and then stimulated overnight with ssRNA40. At the end of this period, supernatants were collected for cytokine ELISA assay. Data are presented as mean \pm SEM. ${ }^{*} p<0.05$. (G) Induction of the expression of pro-IL-1 $\beta$ by ssRNA40 and effect of MKC8866. MDDCs were treated as in the ELISA assays and after overnight incubation, cell extracts were collected and used for the assay of pro-IL-1 $\beta$ and $\beta$-actin proteins by Western blot. $\beta$-actin was used for normalization. A.U., arbitrary units. (H-K) Effect of MKC8866 and fluvoxamine on the expression of the mRNA encoding IFNB1, IFNG, $M X 1$ and $O A S 1$. MDDCs were preincubated with $10 \mu \mathrm{M}$ MKC8866 and $20 \mu \mathrm{M}$ fluvoxamine for one hour and then stimulated with $2 \mu \mathrm{g} / \mathrm{ml}$ ssRNA40 for 4 hours. At the end of this time, the RNA was extracted for $\mathrm{mRNA}$ assay. Data are presented as mean \pm SEM. ${ }^{*} \mathrm{p}<0.05$. $\dagger \dagger$ Ratio paired $t$ test. $\uparrow$ Paired $t$ test two-ways. ¥¥Mann Whitney test. (L-N) Effect of ssRNA40 on the binding of sXBP1 to the promoters of $I L 1 B, I L 6$, and $T N F$. The captions below the graphs indicate the distance from transcription start to the nucleotide positions where PCR primers were selected. The defined sXBP1 binding sites included in the regions spanned by the primers are indicated. Samples were obtained after one hour stimulation by $2 \mu \mathrm{g} / \mathrm{ml}$ ssRNA40. Data are presented as mean \pm SEM. ${ }^{*} \mathrm{p}<0.05 . \dagger \dagger$ Ratio paired $t$ test. 